ISSN (print) 0867-2008 / ISSN (online) 239 I-75 I 2

DOI: http://dx.doi.org/10.12775/OM.2018.001

pp. $7-42$

Julia Pavón Benito*

Departamento de Historia

Historia del Arte y Geografía

Universidad de Navarra

Biblioteca de Humanidades

Pamplona 3 I 009

jpavon@unav.es

Maria Bonet Donato**

Departament d'Història i Història de l'Art

Universitat Rovira i Virgili

Avda. Catalunya 35

Tarragona 43002

maria.bonet@urv.cat

\title{
PAPAL POLICIES TOWARDS THE TEMPLARS AND HOSPITALLERS IN THE CROWN OF ARAGON AND THE KINGDOM OF NAVARRE (12TH-13TH CENTURIES)
}

\section{KEYWORDS}

history; the Middle Ages; military orders; papacy; Templars; Hospitallers; Crown of Aragon; Kingdom of Navarre

\begin{abstract}
The policies of the papacy towards Templars and Hospitallers contributed to their implementation, deployment and protection in the Crown of Aragon and the kingdom of Navarre. Moreover, papal intervention acted as an important upsurge in the defence of their rights and unique status within the church. Therefore, papal bulls were preserved and translated in the regional written traditions as a source of legitimacy and were primordial in the construction of their institutional and historical memory. A significant part of the actions of the popes in relation to the orders were aimed at confirming and defining their characteristics and prerogatives as well as defending them from other powers, especially ecclesiastical ones. This paper explains how the pontiff played a key role in characterising, promoting and situating the military orders as essential institutions in the expansion
\end{abstract}

* ORCID: https://orcid.org/o000-000 I-5806-6094

** ORCID: https://orcid.org/oooo-ooo I-7343-8984 
of the church in the Crown of Aragon and Navarre and, specifically, of the reformist papacy. Despite this favouritism, there were differences between the orders and other ecclesial authorities such as the diocesans. The study focuses on the papal bulls addressed to the North East Hispanic priories, and offers an analysis of the diplomas, addressing the type of issues and circumstances that led to the direct intervention by the pope in Templar and Hospitaller affairs. It also explains what this connection meant and how it was projected by both role-players in ecclesiastic and political arenas, as well as the consequences in the construction of the new ecclesiology.

\section{Introduction. Papal policies and aCtions in favour of the}

TEMPlaRs AND Hospitallers

$\mathrm{T}$

The papacy was a primary agent in the implementation, deployment and protection of the military orders in North Eastern Spain during the $\mathrm{I} 2 \mathrm{th}$ and 13 th centuries. Given the transcendence of pontifical influence, papal interventions were painstakingly recorded and registered by Templars and Hospitallers. The members of these institutions preserved papal bulls and copied, extracted, and even translated them into Romance languages in addition to collecting them in various codices or other types of records throughout the centuries. Therefore, the instruments issued by the popes occupied an important place in the written regional tradition of these orders in Aragon, Catalonia and Navarre and, consequently, in the construction of their institutional and historical memory.

The legitimacy granted by the communion of the Templar and Hospitaller orders with the See of Rome formed part of the identity of the orders, endorsed also by assiduous pontiffs as part of their promotion and protection. To this end, the actions from Rome helped affirm and outline the characteristic roles of Templars and Hospitallers, their way of life and, above all, attempted to fit them institutionally and spiritually into the heart of the ecclesiastical organisation. Furthermore, exemption was a key element in their greater independence in addition to forging their special adherence to the pontiff. ${ }^{1}$ In short, papal policies contributed in defining the nature and corporate image of the orders and acted as an essential bulwark in defending their rights and unique status within the Church, both in the territories of the Crown of Aragon as well as Navarre. Within this context it is relevant to talk about policies, although, according to Thomas W. Smith, papal interventions were in response to specific situations, more than the result of

I Luís García-Guijarro Ramos, "San Juan del Hospital: bulas fundacionales y conformación de los rasgos básicos de la orden en la primera mitad del siglo XII," in La Orden de Malta en España, vol. I, ed. Javier Alvarado y Jaime de Salazar Acha (Madrid: Uned-Sanz y Torres, 20 I 5 ), I09-I I 3 . 
a programmed purpose. ${ }^{2}$ This was probably the case of the papal confirmation of concessions made by the Count of Barcelona to the Templars while settling the will of the king of Aragon, Alphonse I, who bequeathed the Kingdom of Aragon to the military orders. The same occurred with other agreements reached between the episcopal powers and the Templars, which indirectly meant ratifying the solution of the will and testament imposed by Ramon Berenguer IV. ${ }^{3}$ However, as we shall see, there was a series of papal master lines of action, which deserve to be identified as policies. The fact that some papal decisions were renewed by their successors and also copied and kept in the tradition of the order itself, suggests the recognition of a specific policy in favour of the orders.

In view of the relationship between the papacy and the orders of the Temple and the Hospital, the importance of both as reflected in the writings issued and received from the Roman chancellery, mainly in the form of papal bulls, there are two aims to this research. Firstly, to conduct a detailed analysis of the content of the diplomas in an attempt to establish what issues and circumstances led to the direct intervention by the Seat of Peter in Templar and Hospitaller affairs in the northern third of the Peninsula, in other words, the Crown of Aragon and the Kingdom of Navarre. Secondly, after clarifying this complex reality outlined by the primary intervention of pontiffs to protect and defend these institutes, an attempt will be made to correlate what this connection meant to and how it was projected by mediators in the ecclesiastic and political arenas, the consequences and transcendence of said relationships in the construction of the new Roman ecclesiology and the identity of new ecclesiastical organisations in Western Europe. We analyse these issues without losing sight of the importance which the pontifical documental legacy occupied in the institutional memory of the Templars and

2 Thomas W. Smith, Curia and Crusade. Pope Honorius III and the recovery of the Holy Land (I216-I227) (Turhout: Brepols, 20 I 7), I 4-I 8.

3 In I I 50 , Eugene III confirmed the possessions given to the order of the Temple by Ramon Berenguer IV, Count of Barcelona, and later Alexander III took under his protection the Spanish Templars, confirming the donations that they had received, as well as some agreements reached with diocesans powers, Joseph Delaville Le Roulx, "Bulles pour l'ordre du Temple tirées des archives de S. Gervasio de Cassolas," Revue de l'Orient Latin, no. i I (I 905-I 908): 407-408 (Source edition no. I, Eugene III confirme, en les énumérant, les possessions données a l'ordre du Temple par Raymond-Bérenger III, comte de Barcelone) and id., "Bulles," 4I 3-4I 7 (Source edition no. I I, Alexandre III prend les Templiers d'Espagne sous sa protection, et confirme, en les énumérant, les donations qui leur avaient été faites), or Barcelona, Archivo de la Corona de Aragón (henceforth as: ACA), Registro de Cancillería 309, fol. 5, col. I. It had been also confirmed by Adrian IV, see: Cartulaire général de l'Ordre des Hospitaliers de Saint-Jean de Jérusalem (II00-I3IO), vol. I, ed. Joseph Delaville Le Roulx (Paris: Leroux, I 894), no. 267, 20 I. 
Hospitallers, not only as a practical guide for their governing actions but more especially as a primary source of their legitimacy.

\section{i. Papal bulls and letters for Templars and Hospitallers. MAINTAINING THE LEGACY OF PONTIFICAL AUTHORITY}

In relation to the orders, the popes dedicated a significant part of their governing activities to actions aimed at confirming and defining the characteristics and prerogatives of the orders as well as defending them from other powers, especially ecclesiastical, although more occasionally from political power. Our aim is to explain how the pontiff was crucial in characterising, promoting and situating the military orders as essential institutions in the expansion of the Church in the Crown of Aragon and the Kingdom of Navarre and, more specifically in the reformist papacy itself which was being expanded and consolidated. However, this fact did not impede the upsurge of differences or even competitiveness with other ecclesial authorities, such as the diocesans. Indeed, such controversies were resolved by the pontiff favouring the inclusion of the Templars and Hospitallers within the new ecclesiology, while outlining the relationships between the various institutions.

Some of the pontifical diplomas were specifically addressed to priory demarcations and the numerical importance in the Hispanic archives, mentioned by Joseph Delaville Le Roulx, stressed the importance of those addressed to the priory of Navarre. Furthermore, the Castellanía de Amposta and Priory of Catalonia archives also included specific sections for papal bulls and letters. ${ }^{4}$ It is worth remembering that the Castellanía de Amposta was the hospitaller priory of Aragon and Catalonia up to 1319 when it was divided into two: one part Aragonese with the Catalan region of the Ebro, of the same name, and the other Catalan known since then as the Priory of Catalonia. Papal missives and edicts referring to particular matters that arose from various Hospitaller centres were kept in Navarre, yet a significant portion of the documental archive related to the Templars. It is worth highlighting that records of pontifical support for the order of the Temple and even the memoires of the most prosaic affairs, such as debts contracted

4 Les archives de l'ordre de l'Hôpital dans la Péninsule Ibérique, ed. Joseph Delaville Le Roulx (París, Ernest Leroux, I 893), 46-48, 74, 77 and 83-84. As an example, see the old index of documents kept in Barcelona: Liber indultorum et privilegiorum per pontifices, emperatores ac reges christianisimos sacre religioni hierosolimitani concessorum, ACA, Gran Priorato de Cataluña, vol. I I I I. The bulls addressed to the Temple in the index of ACA are one hundred and twenty, which occupy almost fifty pages of the manuscript. 
with said order, were saved and copied in writings by the Hospitallers. ${ }^{5}$ Not just about inherited rights, these memoires were a means to vindicate a shared past and, above all, the legitimacy of the Templar origins of the order of the Hospitallers, following the incorporation of its property and rights. ${ }^{6}$

The original papal letters were a special type of document in the Templar and Hospitaller archives and were copied in various cartularies and kept a posteriori as key parts of the idiosyncrasy and, ultimately, the legitimacy of these institutions. Papal bulls were a significant portion of the documental archive of the orders of Navarre, some concerning the order of the Temple, with around forty having been copied in the 16 th century as well as at later dates in the 18 th century. ${ }^{7}$ Also significant were the papal bulls preserved by the Castellanía de Amposta and Priory of Catalonia, ${ }^{8}$ where more general privileges were preserved in contrast to the more specific ones in Navarre. Templar and Hospitaller codices recorded documents issued by kings together with pontifical documents. ${ }^{9}$ To this end, it could be suggested that the Templars and Hospitallers in Aragon and Catalonia saw the papacy and the monarchy as their main patrons very early on, while recorded documents

5 María Bonet Donato and Julia Pavón Benito, "El paisaje de la memoria de la orden del Hospital en la corona de Aragón y Navarra en la edad media," in Historia de la Orden de Malta. Nuevos Estudios, ed. Javier Alvarado y Jaime de Salazar (Madrid: Dykinson, 20 i 8), 85- I 0.

6 On the value, context and interpretations of written memory and graphic functionality, it is worth mentioning, for example: Isabelle Bretthauer, "La notion d'écriture pragmatique dans la recherche française du début du XXIe siècle," Cahiers Electroniques d'Histoire Textuelle $d u$ LaMOP, 5 (20I2): I-2I, http://lamop-archive.univ-paris I.fr/IMG/pdf/article_Isabelle_ Bretthauer-2.pdf.

7 In the first decades of the I 6th century the Hospitallers in Navarre make a manuscript copying the most important papal letters: Book of copies of papal bulls (undated), Pamplona, Archivo General de Navarra (henceforth as: AGN), Clero, Desamortizados, Convento de sanjuanistas de Puente la Reina, no. 36 . In the i 8 th century, some of the medieval pontifical bulls were reproduced again: Copies of papal bulls (undated), AGN, Clero, Desamortizados, Convento de sanjuanistas de Puente la Reina, no. I60, I6I and I63.

8 Joseph Delaville Le Roulx, "Bulles pour l'ordre du Temple tirées des archives de S. Gervasio de Cassolas," Revue de l'Orient Latin, no. I I ( 1905 - I 908): 405-439 collects up to forty-nine bulls from the Archive of the Crown of Aragon related to the Castellanía de Amposta or what later was the Priory of Catalonia.

9 Hospitaller cartulary, c. I 350 , Madrid, Archivo Histórico Nacional (henceforth as: AHN), San Juan de Jerusalén, Códice L.649; Templar cartularies, I 3 th c., AHN, Órdenes Militares, San Juan de Jerusalén, Códices L.598, L.597. This section of códices of Archivo Histórico Nacional in Madrid is now referenced L.; so from now L.649, L.598 etc. Even king James II kept some of them in the royal chancellery once the Temple was abolished and called: Privilegia Templariorum, ACA, 309 and 310. 
in Navarre preserved references to their pontifical legitimacy up to later dates. ${ }^{10}$ It is possible that the different political processes in these regions, on the death of Alphonse I, the Battler, in I I 34 , would establish a dissimilar roadmap followed by the orders, in relation to royal and Roman powers, a matter that is reflected in the methods and aims used to preserve the written memory.

The papal bulls were of such importance that they were even falsified by some members of the order who were punished and finally denounced in writing so as to reveal the severity of their actions. These actions were reflected in a Catalan version of the Temple rule, which explained how a knight had falsified papal bulls and papal seals under the cover of others. Opprobrium was so significant that it deserved the attention of the provincial chapter and even the general chapter which was meeting in Acre. Its recording in the translation of the rules reflects the importance of papal solutions for the institution's administration and governance. ${ }^{11}$ All things considered and given the weight of pontifical tradition within the Hospitaller order, some of the bulls were then inspected and guaranteed, such as one dating back to I 204, promulgated by Innocent III. The records show that in I 343 , Arnaldo Guillermo Gabastón, archdeacon of Val de Onsella and official from Pamplona, at the request of the procurator the prior of Navarre, was responsible for authenticating this letter from Innocent III addressed to all ecclesiastic authorities recalling the direct dependence of the order of Saint John on the papacy. ${ }^{12}$

\section{I.I. Functions and uses of pontifical records in the archival tradition of the orders}

It is worth noting that general pontifical instructions or those sent to some priories were copied and extracted at different times in codices and other formats. Two cartularies dated at the end of the 13 th century contained papal bulls and royal stipulations addressed to the order of the Temple. Cartulary 597 includes the copy

Io Hospitaller cartularies, I 4th c., AHN, Órdenes Militares, San Juan de Jerusalén, L.649, L.659, (only royal privileges L.662); Bonet and Pavón, "El paisaje de la memoria," 95-98.

${ }^{\prime}$ Judith Mary Upton-Ward, The Catalan Rule of the Templars: Edition and Translation: Barcelona, Archivo de la Corona de Aragón. Cartas Reales, MS 3344, (Woodbridge: The Boydell Press, 2003), $76-78$.

12 Arnaldo Guillermo Gabastón, archdeacon of Val de Onsella and official from Pamplona authenticates a bull from Innocent III dated on 9 June I 204, 9 March I 343, AHN, Órdenes Militares, San Juan de Jerusalén, carpeta (henceforth as: carp.) 85 I, no. 16 and I7. There are more examples - for instance in I 25 I, a letter from Innocent IV sent to Navarre containing, among other things, the full immunity of the Hospitallers in relationship with the jurisdiction of the bishops: Pedro de Legaria, prior of Dominicans authenticates a letter from Innocent IV, I 8 March I 25 I, AHN, Órdenes Militares, San Juan de Jerusalén, carp. 852 , no. 34 and carp. 595 , no. 42 . 
of one hundred and ninety pontifical and royal privileges sent to Templers in the Crown of Aragon, while cartulary 598 accounted for one hundred and three. As specified at the end of this second codex, texts were copied from the Registro Mayor de Privilegios, known as Cartoral de Número, and contained further privileges. These repertories indicate that the archival tradition existed in the order from very early times, aimed at compiling and safeguarding their privileges, ${ }^{13}$ which could be related to the development of a centralised institutional reality under the direction of a prior who, like master Arnaldo de Castellnou, promoted the creation of these codices with the translated bulls. In this case, cartulary 598 was translated to Catalan and cartulary 597 to Occitan. ${ }^{14}$ Given that masters were important political personalities and with enormous capacity to act within the order and externally through various diplomatic activities, it is possible that these records were used to defend their rights and interests. The translation would have helped more explicitly to disseminate their content.

Years later, in mid-I4th century, the so-called castellán of Amposta, Juan Fernández de Heredia, the highest dignitary in the Aragonese priory, commissioned the creation of the Cartulario Magno. This six-volume work established the order's historic memory in the mid-I 4 th century. ${ }^{\text {is }}$ The second volume recorded and copied a significant set of papal bulls together with royal privileges. This extraordinary cartulary was conceived with the purpose of vindicating and disseminating crucial aspects in the disciplinary or institutional conditions and even dogmatic questions of the Hospital. We can refer to another establishment of institutional memory and recourse to papal bulls as the basis for said identity and legitimacy when they were copied in the 16 th century in Navarre, as commissioned by prior Berenguer Sanz de Berrozpe ( 1478 - I 5 I 4). Following the civil war of Navarre and after settling in Navarre in 1498 on returning from Rhodes, Sanz de Berrozpe proceeded to copy a large volume of documents referring to the order with the aim of reorganising the Hospital's assets and rights, to compensate for the

13 Given geographical proximity (Trinquetaille, Avignon, Saint-Gilles), it is possible to cite, among others, the documentary compilations of other Hospital demarcations: Cartulaire de Trinquetaille ed. Paul-Antonin Amargier and Aix: Centre d'Études des sociétés méditerranéennes, Publications universitaires des Lettres et Sciences Humaines d'Aix-en-Provence (Aix-en-Provence: Publications universitaires des Lettres et Sciences Humaines d'Aix-en-Provence, I 972); Cartulaire du prieuré de Saint-Gilles de l'Hôpital de Saint-Jean de Jérusalem (II29-I2IO), ed. Daniel Le Blévec and Alain Venturini (Turnhout-Paris: Brepols, 1997); and Cartulaire et chartes de la commanderie de l'Hôpital de Saint-Jean de Jérusalem d'Avignon au temps de la commune (II70-I250), ed. Claude-France Hollard, Documents, études et répertoires publiés par l'Institut de recherche et d'histoire des textes 63 (Paris: CNRS Éditions, 200I).

14 Templar cartularies, I 3 th c., AHN, Órdenes Militares, San Juan de Jerusalén, L. 597 and L. 598.

is c. I 350, AHN, Órdenes Militares, San Juan de Jerusalén, L.649. 
lack of management by prior Juan de Beaumont ( $1422-1487$ ). ${ }^{16}$ In fact, on I 6 December 1499 at the request of the prior, King John and Queen Catherine ordered the auditors of Comptos ${ }^{17}$ to fulfil any request by Berenguer in relation to the copying of documents. ${ }^{18}$ This scenario suggests that the creation of a manuscript exclusively containing copies of papal bulls dated from the beginning of the i6th century and safeguarded in the General Archive of Navarre but originating from the archives the Order held at the Convent of the Crucifix in Puente la Reina, may date back to those times. ${ }^{19}$

The Temple and the Hospital had a centralised administration ${ }^{20}$ yet had very pronounced unitary identities, which rightfully explains the production of these types of documental volumes and their handling by dignitaries. ${ }^{21}$ This unique understanding is also what the papacy itself had established in the foundational pa-

16 Patricia Burgui Fernández, "El priorato navarro de la orden de San Juan de Jerusalén a finales de la Edad Media. Berenguer Sanz de Berrozpe ( 1478 - I 5 I 4)" (PhD diss., Universidad de Navarra, 20I4), 244-245.

17 The auditors of Comptos, made up of four persons, were the members of the Chamber of the Comptos (Tribunal which oversaw the management of royal finances in Navarre), audited the income and expense accounts of the collectors and functionaries who handled the public funds of the Crown. Javier Zabalo Zabalegui, La administración del reino de Navarra en el siglo XIV (Institución Príncipe de Viana: Pamplona, I 973), I 26-i 27.

18 King John and Queen Catherine of Navarre order to copy documents requested by the Hospitaller Prior of Navarra, Berenguer Sanz de Berrozpe, December I 499, AHN, Órdenes Militares, San Juan de Jerusalén, carp. 9 I O, no. 3 I.

19 These copies were made during the time of the Prior of Navarre, Berenguer Sanz de Berrozpe, who reorganized the Priory of Navarre, see above (note 7 ). This activity is reflected, for example, in the copy of bulls in 1 503: Celestine III praises the heroic actions of the Templars as defenders of the Church, 25 June I I 94, AHN, Órdenes Militares, San Juan de Jerusalén, carp. 85 I, no. I I, and Innocent III copies the bull of Celestine III that praises the heroic behaviour of the Templars as defenders of the Church, 25 September I 207, AHN, Órdenes Militares, San Juan de Jerusalén, carp. 85 I, no. 20.

20 Maria Bonet Donato, Orden del Hospital en la Corona de Aragón: Poder y gobierno en la Castellania de Amposta (CSIC: Madrid, 1994), 8I-206 and 235-275; Karl Borchardt, "The Military-religious orders: a medieval 'school for administrators'?", in The Military Orders, vol. 5, Politics and Power, ed. Peter W. Edbury (Aldershot, Hampshire: Ashgate, 20 I 2), 3-22.

${ }_{21}$ See note i 3 . See also: Michael J. Peixoto, "Copies and cartularies: modernizing Templar documents in mid-thirteenth-century Champagne," in The Templars and their sources, ed. Karl Borchardt, Karoline Döring, Philippe Josserand and Helen Nicholson (Abingdon, Oxon: Routledge, 2016), 64-77. Cf. Damien Carraz, "Le cartulaire du Temple de Saint-Gilles, outil de gestión et instrument de pouvoir," in Les cartulaires méridionaux (actes du colloque de Béziers les 20 et 2 s septembre 2002 par le Centre historique de recherches et d'études médiévales sur la Méditerranée occidentale, ed. Daniel Le Blévec (París: Bibliothèque de l'École des Chartes, 2016), I 45-I62; and Daniel Le Blévec and Alain Venturini, "Cartulaires des Ordres Militaires. XIIe-XIIIe siècles (Provence occidentale- Basse vallée du Rhône)," in Les Cartulaires, actes de la table ronde organisée par l'École nationale des chartes et le GDR I2I du CNRS (Paris, 5-7 décembre 
pal bulls and set out to endorse through its actions in relation to the military institutions. Moreover, the papacy promulgated several bulls which were similar in content and even identical for Templars and Hospitallers. ${ }^{22}$ To this end, the orders were viewed from Rome as the ideal instruments to strengthen pontifical authority and centralisation in the context of the new ecclesiological reality between the 12 th and 13 th centuries. Likewise, they were the vehicles for the expansion of Christianity beyond their borders, under the auspices of the crusade fight "against the enemies of the faith". The papal bulls received in each of the European regions by the Templars and Hospitallers, and in the case of Navarre and the Crown of Aragon codified these pontifical messages repeatedly under the common denominator of renowned ecumenism by and for said orders as the best guarantors of the new ecclesiological conception.

\section{Pontifical promotion AND pRotection: ReQUests for Aid, JUSTIFICATION AND DEFENCE OF THE ORDERS}

The arrival and promotion of military orders in Hispanic territories was largely due to a series of actions by the papacy, such actions being connected with the needs of the political powers and social relations that predominated at the time. During the first decades, as noted by L. García-Guijarro, said papal promotion

I99I), ed. Olivier Guyotjeannin, Michel Parisse and Laurent Morelle (Paris: École des Chartes, 1993), 458-459.

22 This happened, for instance, under the pontificate of Innocent III. With the intention of protecting the Hospitallers' activities, he issued a bull in I 202 which copied the contents of one addressed to the Temple in I 198 , Innocent III forgave the seventh part of the penance to those who help the Templars or register in their brotherhood, I 9 January I I99, AGN, Clero, Desamortizados, Convento sanjuanista de Puente la Reina, no. 36 , fol. $32 \mathrm{r}$ and $3 \mathrm{r}-\mathrm{v}$; summarised by Jose Goni Gaztambide, see: Jose Goni Gaztambide, "Regesta de las bulas de los archivos navarros (I I 98-I 417)," Principe de Viana, no. 25 I (2010): 622-623 (Source edition no. 4, Inocencio III perdona la séptima parte de la penitencia a los que socorran a los templarios o se inscriban en su cofradía [...]) and Goni Gaztambide, "Regesta," 623 (Source edition no. 7, Inocencio III repite el contenido de la bula del 27 de septiembre de i 198 en favor de la orden del Hospital). Two years later in I 206, the pope copied to the Hospital another one given to the Temple in I I99, see: Innocent III, addressing all the bishops and prelates of the Church, complains about the bad treatment given of Templars, I I December I I99, AHN, Órdenes Militares, San Juan de Jerusalén, carp. 85 I, no. I 3 ; and Innocent III, addressing all the bishops and prelates of the Church, complains about the bad treatment of Hospitallers, 25 January I 206, AHN, Órdenes Militares, San Juan de Jerusalén, carp. 85 I, no. i 8 and I 9 . Also for the Hospital, see: Cartulaire général, I, ed. Delaville, no. 752 ( I 1 85) and for the Temple, Delaville Le Roulx, "Bulles," 423 (Source edition no. 26, Grégoire IX défend aux prélats de faire condemner par les officialités les Templiers à des peines pécuniaires). 
also indicated the differences between Templars and Hospitallers, as well as their relationships with the papacy. ${ }^{23}$

Our study particularly covers the promotional papal instruments worth saving in the archives and the diplomatic tradition of the knights of the Crown of Aragon and the Kingdom of Navarre. Many of these documents reflect the importance and recurrence of the zeal and promotion exercised by the pontiff towards the Temple and the Hospital. These texts insisted on the distinctive roles of both orders in relation to all other regular organisations, and somehow socially promoted them by introducing certain spiritual and religious benefits to the members of their brotherhoods. To this end, in I 46 pope Eugene III explained to ecclesiastic dignitaries that the order of the Temple defended the Church in the East, cleansed these lands of paganorum spurtitia and protected pilgrims visiting Holy Sites. ${ }^{24}$ Therefore, he demanded that people join these brotherhoods and, as spiritual encouragement, offered pardons of the seventh part of their penitence. Particularly noteworthy is that the date of this papal bull found in the Navarrese archives chronologically coincides with the first development of a Templar brotherhood in the middle valley of the Ebro, specifically in the commandery of Novillas, highly esteemed by the nobility. The extensive list of members is still kept in the National Historical Archive. ${ }^{25}$

However, the spiritual benefits for those who helped the orders, such as those granted by Adrian IV in I 55 to Hospital benefactors, did not always refer to their military or other services. ${ }^{26}$ In this case, the Pope exhorted the prelates of Christianity to promote aid to the Hospital in exchange for partial annual indulgence, specifically, the seventh part of their penitence and other privileges such as the lifting of an "interdict" for mass and maintaining ecclesiastic burial. ${ }^{27}$

23 Luis García-Guijarro Ramos, Papado, Cruzadas y Órdenes Militares (Madrid: Cátedra, I 995), $79-89$ and I $23-$ I 29.

24 Eugene III exhorts Christians to help the Templars and integrate into their brotherhoods, I 3 November I I 46/ I I 49, AGN, Clero, Desamortizados, Convento de sanjuanistas de Puente la Reina, no. 36, fol. 3 Iv- 32 r.

25 Antonio Ubieto Arteta, "Cofrades aragoneses y navarros de la milicia del Temple (siglo XII). Aspectos socio-económicos," Aragón en la Edad Media, no. 3 ( 1980 ): 29-93.

26 For decades these brotherhoods were important for the orders as reflected in the papal missives, Adrian IV exhorts the prelates of Christianity to promote among the faithful help for the Hospital of Saint John of Jerusalem, I 4 March I I 5 , AGN, Clero, Desamortizados, Convento de sanjuanistas de Puente la Reina, no. 36, fol. i sr; cf. Cartulaire général, I, ed. Delaville, no. I 30 , 107 and no. 236, which is a renewed version of the bull "Quam amabilis Deo" from Innocent II, with some variations.

27 Delaville Le Roulx, "Bulles," 4 I 8 (Source edition no. I 4, Lucius III engage les prélats à exhorter les fidéles à faire des quétes pour les Templiers [...]) ( I I 83 ). Probably the indulgences provided to the combatants and those who contributed with alms for the expansion of Christianity were 


\section{I. Papal defence of Templars and Hospitallers as defenders of Christianity}

The fight against the Muslims was a fundamental part of the deployment of the military orders in the Iberian Peninsula, but even more so it was an indicator of their mission in the heart of Christianity. Therefore, it is worth observing how the papal missives in our archives were above all requests to help the orders. The papal bulls fostered the participation of said institutions in the conquests and battles of the mid- $\mathrm{I} 2$ th century, only occasionally considering the Hispanic scenario. ${ }^{28}$ This posture is exemplified in the actions of the pontifical legate who exhorted archbishops, Templars, Hospitallers and other prelates to fight against the Muslims at the request of kings, princes and the Hispanic people, as mentioned in their petition circa I I $55 .{ }^{29}$ Moreover, these bulls stipulate that those who displayed the cross on their chests against said enemies would obtain clemency from God and urged the military orders to join the Roman Church through these brotherhoods. The petition from the legate Jacinto was directed at the entire Church and its higher powers, yet explicitly referred to the Templars and Hospitallers.

A few of the papal bulls addressed to the orders were intended to remind them of their military commitments in the Iberian Peninsula. Some bulls simply relayed their obligations, specifically when at end of I 2 th century the Almohades broke the Christian front, taking advantage of the division among the Hispanic kings. ${ }^{30}$ To this end, Celestine III reminded Hospitallers in the Iberian Peninsula and in Provence in I 193 that they should not participate in fights among Christians. ${ }^{31}$

promoted by the papacy from early I 2 th century, Étienne Magnin, "Indulgences," in Dictionnaire de théologie catholique contenant l'exposé des doctrines de la théologie catholique, leurs prenves et leur histoire, vol. 7, part 2, ed. Alfred Vacant, with Euge`ne Mangenot (Paris: Letouzey et Ané, 1923), I607-1610.

28 The calls of the papacy for the military interventions in projects led by Hispanic kings, and responding to their requests are studied in: José Goñi Gaztambide, Historia de la bula de la Cruzada en España (Vitoria: Editorial del Seminario, 1958), 63- 109, and Francisco García Fitz y Feliciano Novoa Portela, Cruzados en la reconquista (Madrid: Marcial Pons Historia, 20 I 4), I 33 and 138 .

29 La documentación pontificia hasta Inocencio III ( $965-I 2 I 6)$, ed. Demetrio Mansilla (Roma: Instituto Español de Estudios Eclesiásticos, I 955 , I), no. 98.

30 Paul Kehr, El Papado y los reyes de Navarra y Aragón hasta mediados del siglo XII (Zaragoza: Artes Gráficas E. Berdejo Casañal, I 946), ı o I; Carlos de Ayala Martínez, "De Toledo a las Navas: la reconquista se convierte en cruzada," in Órdenes Militares, monarquia y espiritualidad militar en los reinos de Castilla y León (siglos XII-XIII), ed. Carlos de Ayala Martínez (Granada: Universidad de Granada, 2015), 24-32.

${ }^{3}$ Papsturkunden in Spanien: Vorarbeiten zur Hispania Pontificia. II, Navarra und Aragon, I, Archivberichte, vol. 2, part 2, ed. Paul Kehr (Berlin: Weidmann, I 928), no. 200 and El Gran Priorato de Navarra de la Orden de San Juan de Jerusalén (siglos XII-XIII), vol. 2, ed. Santos García Larragueta (Pamplona: Institución Príncipe de Viana, 1957), no. 72. Along these lines, 
Decades later, Templars and Hospitallers were requested by Pope Innocent IV ${ }^{32}$ to help King James I against the Muslims, and afterwards he reproached them for not cooperating with the king, reminding them of their commitment to fight against Islam in 1250 and threatening to excommunicate those who prevented Hospitallers from participating in fighting against the Muslims. ${ }^{33}$

Outstanding in the list of promotional papal letters were those aimed at requesting aid and promoting the fight for Christianity, defence of the pilgrims and Holy Places and those aimed at supporting economic aid for such purposes. Requests for aid for the order of the Temple soon made mention its military role. Accordingly, a series of bulls, such as the one issued by Eugene III around I I 48, exhorted the prelates to help the Templars who were the defenders of Christianity, by granting spiritual benefits to the followers. The provisions stated that, if the Templars asked for alms in places under interdict, prelates could open the churches once a year. This exception fostered requests for aid. These instructions were repeated in other later papal bulls such as those issued by Lucius III and Innocent III..$^{34}$

\subsection{Papal request for alms for activities of the orders in the Holy Land}

The request for economic aid, in other words, alms, was a primary part of pontifical activities in the aforementioned Hispanic territories. Alexander III (I I 59- I I 8 I), one of the great advocates of ecclesiastic reform and promoter of the III Lateran Ecclesiastical Council, sent a series of requests to bishops and other ecclesiastic dignitaries to promote alms intended to defray the costs of the Templars' activities overseas. ${ }^{35}$ The pope's request recalled once again that "the Templars defended

Innocent III was mainly interested in promoting peace among the Spanish kings, Demetrio Mansilla, "Inocencio III y los reinos hispanos," Anthologica Annua, no. 2 ( 1954), I 9-34.

32 Regesta de letras pontificias del archivo de la Corona de Aragón. Sección Cancillería Real (Pergaminos), ed. Francisco J. Miquel Rosell (Madrid: Cuerpo de Archiveros, Bibliotecarios y Arqueólogos, I 948), no. I 6 I and La documentación pontificia de Inocencio IV (I243-I254), ed. Augusto Quintana Prieto (Roma: Instituto Español de Historia Eclesiástica, I 987 ), no. 6 I 6.

33 Cartulaire général de l'Ordre des Hospitaliers de S. Jean de Jérusalem (IIO0-I3IO), vol. 2, I20I-I260, ed. Joseph Delaville Le Roulx (Paris: Ernest Leroux, i 897), no. 25 I 7 ( I 250 ).

34 Eugene III exhorts the prelates to help the Templars, defenders of Christianity, 20 March [ I I 48], AHN, Órdenes Militares, San Juan de Jerusalén, carp. 85 I, no. 3, and Lucius III exhorts the prelates to help the Templars, defenders of Christianity, 29 September [ I I 8 I / I 85 ], AHN, Órdenes Militares, San Juan de Jerusalén, carp. 85 I, no. 5, and published, Papsturkunden für Templer und Johanniter: Archivberichte und texte, ed. Rudolf Hiestand (Göttingen: Vandenhoeck \& Ruprecht, I972), no. I 46.

3527 May [I I59/I I 8 I] , AHN, Órdenes Militares, San Juan de Jerusalén, L.597, fol. 35-36, no. 16 . 
the eastern church from the enemies del nom cristia...e als peregrins cristians, lo loc sant...en segur viatge". The safety of pilgrims continued to be a Templars identity sign, as it was for the Hospitallers, and furthermore, the bull by Alexander III specified that alms were aimed at defraying the costs of weapons and other needs. ${ }^{36}$

The Hospital was promoted by the papacy in similar terms as that of the Temple, although the role of assistance was a main reference. Alexander III vindicated the caring role that its members exercised with the poor and pilgrims in Jerusalem, ordering the ecclesiastic authorities to exempt the members of brotherhoods from paying the seventh part of their obligations and vindicating other exemptions for the members of the order as well. ${ }^{37}$ Another bull by Honorius III also offered pardon for a seventh of the penitence to those who contributed, whether as members of the brotherhood or with alms, to defending Christianity and the eastern lands. ${ }^{38}$

In fact, the question of alms, understood as a means to favour the services provided by the knights in the Holy Land as well as in the war against infidels, received remarkable pontifical attention as was evident in other papal bulls addressed to the Hospital in the 13 th century. ${ }^{39}$ These contributions were of such importance that they collided with episcopal customs and rights which were generally resolved in favour of the orders by papal intervention. Alexander III ordered the ecclesiastic authorities not to allow certain ecclesiastics to prevent the collection of alms in favour of the Hospitallers or claim part of the collection. ${ }^{4}$

36 AHN, Órdenes Militares, San Juan de Jerusalén, carp. 594, no. I and Alexander III orders the ecclesiastical authorities to allow the quaestors of the Hospital of St. John of Jerusalem to publish the confraternities of the order and to beg for alms, 2 March [I I 59/ I i 8 I], AGN, Clero, Desamortizados, Convento de sanjuanistas de Puente la Reina, no. 36 , fol. I $3 \mathrm{r}-\mathrm{v}$.

37 Alexander III to the prelates, I 3 June [ I I 59/ I I 8 I], AHN, Órdenes Militares, San Juan de Jerusalén, L.649, fol. I 8- I 9, no. 27 and I 5 May, AHN, Órdenes Militares, San Juan de Jerusalén, L.649, fol. 28-29, no. 39, following previous ones from Adrian IV and Innocent II: Adrian IV exhorts the prelates of Christianity to promote help for the Hospital of Saint John of Jerusalem among the faithful, i 4 March i I 55, AGN, Clero, Desamortizados, Convento de sanjuanistas de Puente la Reina, no. 36 , fol. is r.

38 November 28, I 2 I 9, AHN, Órdenes Militares, San Juan de Jerusalén, L.649, fol. 4-5, no. 6.

39 Honorius exhorted the faithful to make these contributions in 1217 , January 231217 , AHN, Órdenes Militares, San Juan de Jerusalén, carp. 600, no. I 45 or carp. 853, no. 4 I (I 253 ). Also, in the Catalan archives of the Temple, a request for economic aid to help in the Holy Land is preserved, although addressed to German lands in I 256, Delaville Le Roulx, "Bulles," 427-428 (Source edition no. 36, Alexandre IV authorise le grand-maitre et les freres du Temple a percevoir, en Allemagne et partout ailleurs qu'au royaume de Jérusalem [...]).

40 Alexander III orders the ecclesiastical authorities not to allow certain priests to prevent the collection of alms in favour of the Hospital, is May [ I I 59/ i I 8 I ], AGN, Clero, Desamortizados, Convento de sanjuanistas de Puente la Reina, no. 36, fol. I $3 \mathrm{v}-\mathrm{I} 4 \mathrm{r}$; summarised in Juan Carrasco Pérez, "Bulas Sanjuanistas del Gran Priorato de Navarra ( I I I 3 - I 3 I 2)," Anuario de Estudios 
The same pope recommended that the Templar dignitaries from the East that visit the West to obtain help from princes and counts to defend the Crusade states, and all those who help the Templars and Hospitallers, to defend Christianity, be granted indulgences. ${ }^{41}$ Another papal bull by Alexander III, addressed to the main political powers such as kings and counts, recalled the contributions of both orders to the Holy Land and communicated the indulgences granted to those who travelled there. ${ }^{42}$ More general appeals were also made, such as the one by Lucius III ( 1 I 84) endorsing a crusade to save the Holy Land..$^{43}$ The dignitaries of these orders also sent out requests at the same time as those disseminated by the papacy, such as the one presented by the Hospital master to the ecclesiastic hierarchy around I I 93 or to King Sancho VII of Navarre. Curiously and significantly, these missives were copied in the Navarrese archives. ${ }^{44}$

\subsection{Papal communications in defence of the crusading mission of the Hospitallers and Templars}

Throughout the 12 th and 13 th centuries, papal documents outlined the conditions for the knights as part of the eastern crusade, occasionally mentioning their forbearance and their charismatic value as defenders of Christianity. For instance, one papal intervention in 1266 recorded in the Templar cartulary translated to Catalan specified how much the knights Templar had suffered and how they had been beheaded, murdered and wounded, ${ }^{45}$ apparently recalling the battle of Hattin ${ }^{46}$ an episode that had gone down in the order's "legend". Part of this narrative tradition, regarding the crusades in which the papacy contributed to disseminating the promotion of the orders, exist in other papal communications. During the

Medievales, no. I I (1981): 523 (Source edition no. I 4, Honorio III ordena a la jerarquía recibir benignamente a los hospitalarios que fuesen presentados como idóneos).

${ }^{41}$ Alexander III to the prelates, 22 February [ I I 59/ I I 8 I ], AHN, Órdenes Militares, San Juan de Jerusalén, L.597, fol. 32-33, no. I 4: e acorren en remissio de lurs peccats com per aquels frares del Temple e per los frares del Espital, la Crestiantat sia la sens dubte confermada.

42 In a marginal note: indulgencias a los que passaran a la Terra Santa e a los que faran ayuda a los passantes, 28 June [I I 59/ I I 8 I ], AHN, Órdenes Militares, San Juan de Jerusalén, L.649, fol. $19-20$, no. 29.

43 Lucius III appeals for the Crusade to the Christians, so that they go in aid of the Holy Land, ıo December [ I I 84], AGN, Clero, Desamortizados, Convento de sanjuanistas de Puente la Reina, no. 36, fol. 29r-3or.

44 El Gran Priorato de Navarra, 2, ed. García Larragueta, no. 73, 85, 86 and 87.

45 Clement IV to the archbishops, bishops and ecclesiastics, 4 March I 266, AHN, Órdenes Militares, San Juan de Jerusalén, L.598, fol. I, no. 2.

46 Malcolm Barber, "Supplying the Crusader States: The Role of the Templars," in Crusaders and Heretics, I2th-I4th Centuries, ed. Malcolm Barber (Aldershot: Ashgate, I 995), 3 I 5. 
final years of Christian domination in the Holy Land, some bulls referred to the difficulties the two orders faced with their defence and even Pope Celestine V, in I 294, claimed the property the orders had possessed once the loss was definitive. ${ }^{47}$

The tumultuous and transformational times in the eastern domains in the final decades of the $\mathrm{I} 2$ th century coincided with a period of papal affirmation with Alexander III and, later, Innocent III, the highest representatives of the progress made towards conciliating and consolidating the papacy as a government institution at the time. Both popes supported the military orders and launched repeated requests for help for them, defending their privileges within the Church. As was traditional in writing papal bulls, these popes were to validate and reuse previous solutions yet, despite the circumstances, both dedicated outstanding attention to fostering the Templars and Hospitallers in line with the institutional affirmation of the papacy and the medieval Church..$^{8}$ In I I 99, Innocent III recovered the papal bulls of Eugene III and Lucius III to encourage people to join the Temple brotherhood in order to defend the Holy Land, thus promoting the receipt of alms for the same purpose. ${ }^{49}$ Once again, and using earlier texts as examples, spiritual benefits were restored. In a more general sense, Innocent III called on the Hospitallers to take the cross in $1200.5^{\circ}$

\section{THE POSITION OF THE ORDERS IN THE NEW ECCLESIOLOGICAL PROGRAM} AND RELATIONS WITH DIOCESAN POWERS

Although papal actions protecting the orders were part of and justified by the paradigms of the dilatatio Christianitas, this new ecclesiology, which emerged at the end of the I ith century and defined throughout the first three general Lateran councils, was also brought about by these cross-border institutions. As indirect agents of the reformist process, the Hospital and the Temple received support for their entire complex institutional organisation which did not initially conform to the European diocesan regional map. In relation to the perception of rights and

47 I 4 September I 294, AHN, Órdenes Militares, San Juan de Jerusalén, L.649, fol. 3 I, no. 4 I.

48 García-Guijarro, Papado, 84-87 and I 29- I 3 I.

49 See: Lucius III exhorts the prelates to help the Templars, defenders of Christianity, 29 September [I I 8 I/ I I 85 ], see above (note 34); see also: Eugene III exhorts Christians to help the Templars and integrate into their brotherhoods, I 3 November I I 46/ I I 49, see above (note 24), and Innocent III forgave the seventh part of the penance to those who help the Templars or register in their brotherhood, I 9 January I I 99, see above (note 22), 32r-v. Also in the Occitan version AHN, Órdenes Militares, San Juan de Jerusalén, L.597B, fol. 65-66, no. 33 and fol. 53-6I, no. 30 .

so La documentación pontificia hasta Inocencio III, ed. Mansilla, no. $26 \mathrm{I}$. 
their projection over the Aragonese, Catalan and Navarre territories in the form of construction and spiritual attention of churches, oratories, cemeteries and masses at times debilitated the relations between these orders and the diocesan church authorities or other institutions. The actions taken by the orders to preserve the pope's protective words ended up forming part of the orders' archival legacy. These institutions reflected and recalled that the arbiter and head of Christianity over the complex political and diocesan map was the Roman pontiff.

\section{I. The articulation of diocesan ecclesiastic scenarios in view of the Temple and the Hospital}

As outlined, the Hospital of Saint John of Jerusalem had a special dependent relationship with the Seat of Peter since the very first papal bull in I I I 3, issued by Paschal II. Its close ties to Rome gradually surfaced with other apostolic actions in I 35 and I I 54 , securing various jurisdictional rights over the episcopal authorities. ${ }^{\text {sI }}$ In the case of the order of the Temple, the confirmation in March I 139 by Innocent II of the aims of this brotherhood in the papal bull Omne datum optimum, ${ }^{52}$ and later, in the papal bulls Milites Templi, by Celestine II in I I44, and Militia Dei, by Eugene III in I I 45, comprised the foundations for the development of an institution which served the papacy.53

This direct dependency on the pontiff was the subject of debate with other ecclesial powers as occurred with the diocesans, in view of the documental tradition conserved. Precisely, the resistance that some Church dignitaries deployed towards the orders partially explains why the missives, which discussed direct guardianship in relation to the papacy's jurisdiction, were kept or copied in the provincial archives. For example, in a letter from Innocent III addressed to the ecclesiastic hierarchy it specified that the order of Hospital, members, churches, commanderies and convents report directly to the Holy See. Therefore, only the pope could intervene in matters related to the institution, receive taxes and pronounce excommunications or interdicts. Moreover, the letter urged bishops and prelates to address any complaints to the pope. ${ }^{54}$ Likewise, a I 22 I bull by Honorius III addressed to prelates counselled them not to proceed with any excommunications against the Templars, recalling that they had no other dignitary than the

51 García-Guijarro, "San Juan," I I o- I 2 I.

s2 Marquis D'Albon, Cartulaire Général de l'ordre du Temple, IIIg?-IIso (Paris: Honoré Champion, I 9 I 3), 375-379 no. 5; Papsturkunden, ed. Hiestand, no. 3.

53 García-Guijarro, Papado, 82.

54 Arnaldo Guillermo Gabastón, archdeacon of Val de Onsella and official from Pamplona authenticates a bull from Innocent III dated on 9 June I 204, 9 March I 343, see above (note I 2), from a vidimus made at 1342 , and another no. I 7 ( 1204 ). 
pontiff and insisted that no other jurisdiction could affect them. ${ }^{55}$ Another letter from Innocent IV ( 25 I) reiterated full immunity for the Hospitallers with respect to the ordinary jurisdiction of the bishops. ${ }^{6}$ More specifically, other papal letters consented to Hospitallers testifying in disputes relating to their institution, as had been done by Alexander III, and confirmed by Alexander IV in I $255 .{ }^{57}$

The right to be subject to the papacy and exempt from the diocese were vindicated by the orders themselves against demands from the bishops. Thus, for example, the dignitaries of the Hospitaller commandery of Susterris argued that they did not have to make certain payments to the diocesan of Seu de Urgell because of their papal privileges and protection. They wanted to avoid the payment of expenses related to the visit of the Apostolic legates to the provincial ecclesiastical council of Tarraconense in I 292, which were claimed by the Bishop of Seu de Urgell. To do so, they insisted that the institution depended on the pope and that it was under its special protection. ${ }^{58}$ However, it is worth mentioning that we have collected mostly proclamations and vindications from the archives of the orders. Other papal missives did not always coincide with the view that the order did not have to pay, such as one by Innocent III demanding payments from the Templars, Hospitallers and other ecclesiastics for the bishop's visit. ${ }^{59}$

Templars and Hospitallers received a series of ecclesiastic rights from the papacy in the 12 th and 13 th centuries which were recorded in the Aragonese, Catalan and Navarrese archives. To this end, they obtained permission to have oratories, churches and cemeteries built under their foundations as well as other financial benefits such as tithes. ${ }^{60}$ Roman interventions acted as prompts for the full accept-

\$5 20 January I 22 I, AHN, Órdenes Militares, San Juan de Jerusalén, L.598, fol. 20, no. 2 I.

56 Pedro de Legaria, prior of Dominicans authenticates a letter from Innocent IV, I 8 March i 25 I, see above (note I 2 ).

57 Alexander IV confirms the privilege of Innocent IV to the Hospitallers, I 3 January I 255, AHN, Órdenes Militares, San Juan de Jerusalén, carp. 855, no. 91.

58 I 9 April I 292, ACA, Órdenes Religiosas Militares, Gran Priorato Cataluña, carp. 7, no. I 93.

59 La documentación pontificia hasta Inocencio III, ed. Mansilla, no. I79.

60 El Gran Priorato de Navarra de la Orden de San Juan de Jerusalén (siglos XII-XIII), vol. I, ed. Santos García Larragueta (Pamplona: Institución Príncipe de Viana, I 957), 253 and 254; or the right to receive alms: Celestine III orders the prelates to allow the knights of the Hospital to ask for and receive alms and preach in their churches, I 3 May I I 9 I, AHN, Órdenes Militares, San Juan de Jerusalén, carp. 85 I, no. Io. For the Temple, see: Alexander III to the prelates, 7 May [I I 59/ I I 8 I], AHN, Órdenes Militares, San Juan de Jerusalén, L.597, fol. 44 and 45, no. 23; Alexander III to the prelates, 7 May [I I 59/ I I 8 I ], fol. 25, no. 8, and others: Innocent III defended the right of the Templers of perceiving tithes, 22 June I I99, fol. 82-84, no. 49, etc.; cf. Celestine III praises the heroic actions of the Templars as defenders of the Church, 25 June I I94, see above (note I9). Some other pontifical privileges of confirmation of ecclesiastical prerogatives to the Hospitallers: such as one from Innocent III, 22 August I I 98, AHN, Órde- 
ance of the military orders among other ecclesiastic institutions, precisely reaching full ecclesiological adequacy. It must not be forgotten that these papal policies reinforced the religious role and, to a certain extent, the safe observance of spiritual obligations by their members and dependants. However, it is worth noting that some of the prerogatives granted by the papacy were connected to specific roles and needs which attempted to adapt these institutions within a more complex and complete ecclesial map.

Some papal provisions in favour of Templar ecclesiastic rights were sent to bishops, such as those of Lleida, Pamplona and Huesca, to protect knights from the meddling of diocesans in their prerogatives. ${ }^{61}$ An outstanding series of papal bulls urged bishops and other ecclesiastic dignitaries to respect the Hospitallers' privilege, ${ }^{62}$ such as their right to receive alms. ${ }^{63}$ With these interventions, the papacy helped place the Hospitallers in an ecclesial framework on the understanding that the leading dignitaries in the territory must ensure the efficacy of the pope's resolutions. ${ }^{64}$ However, the diocesan powers opposed the ecclesiastic rights of the

nes Militares, San Juan de Jerusalén, carp. 599, no. I I 9; Innocent III wrote to the prelates and defended Hospitallers' ecclesiastical rights, 7 June I 204, AHN, Órdenes Militares, San Juan de Jerusalén, carp. 594, no. I 5; similarly, I 3 February I 208, AHN, Órdenes Militares, San Juan de Jerusalén, carp. 594, no. I9; and Gregory IX addressed to the Hospitallers and defended their ecclesiastical privileges, 7 May I 228, AHN, Órdenes Militares, San Juan de Jerusalén, carp. 600, no. 142 and I 43 ; and carp. 595 , no. 32.

6r Eugene III to the bishop of Lleida, I 5 March i I 5 I, AHN, Órdenes Militares, San Juan de Jerusalén, L.597, fol. I I 4, no. 77; Eugene III to the bishops of Zaragoza, Pamplona, Huesca and Tarazona, 9 September [I I 45/ I I 53], fol. I I 5-I I 6, no. 79, and for bishops in general, 7 April [I I 45/I I 53], fol. I I 4-I I 5, no. 78 and others in the same codex.

62 E.g. in I I 99: Delaville Le Roulx, "Bulles," 419 (Source edition no. I6, Innocent III ordonne aux prélats de faire observer les priviléges des Templiers en matière de sépulture); in I 209: id., "Bulles," 42 I (Source edition no. 22, Innocent III ordonne aux prélats de protéger les biens et les priviléges des Templiers contre les usurpateurs, et d'excommunier quiconque ne se soumettra pas à leurs injonctions); in I 227: id., "Bulles," 422 (Source edition no. 25, Grégoire IX ordonne aux prélats de faire rendre justice aux Templiers molestés par les paroissiens desdits prélats); in I 245 : id., "Bulles," 423 (Source edition no. 27, Innocent IV ordonne à l'éveque, au sacristain et à l'archidiacre d'Huesca de mettre un terme aux incursions de divers seigneurs sur les biens du Temple dans le diocèse d'Huesca), and in I 258: id., "Bulles," 428-429 (Source edition no. 37, Alexandre IV ordonne à l'évéque de Saragosse de protéger les Templiers d'Aragon et de Catalogne et leur biens contre quiconque tenterait de les molester).

63 Alexander III to the prelates, [I I 59-I I 8 I ], AHN, Órdenes Militares, San Juan de Jerusalén, L.649, fol. I 9, no. 28 and Cartulaire général, I, ed. Delaville, no. 392.

${ }_{64}$ Lucius III exhorts the prelates to respect the ecclesiastical privileges of the Hospitallers, $29 \mathrm{Fe}-$ bruary I I 84, AHN, Órdenes Militares, San Juan de Jerusalén, carp. 600, no. I 45 ; Lucius III to the prelates, 25 April i 84, AHN, Órdenes Militares, San Juan de Jerusalén, carp. 594, no. 4, and 9 November I I 84, no. 6; see also: Urban III renews the bulls of Alexander III and Lucius III, I 6 July i I 86, AHN, Órdenes Militares, San Juan de Jerusalén, carp. 599, no. I 45, and 7 June 
orders, which led to recurrent disputes. Many pontifical solutions were favourable to the Templars and Hospitallers and were recorded in their codices. The necessity of these institutions to put these rights into writing and convert them into historic memory reflected the transcendence of their vindications and defence of ecclesial spaces and roles, upholding pontifical instruments as guarantees of their rights. Such identification with the See of Rome was expressed by the Hospitaller Guillermo de Laurag upon welcoming a new member in $117 \mathrm{I}^{65}$

\subsection{Specific ecclesial prerogatives of the orders under pontifical protection}

The Templars and Hospitallers enjoyed many ecclesiastic prerogatives especially pontifical privileges which allowed them or, in some way, ordered them to erect oratories in lands taken from the Muslims and near borders. This mission complied with what was one of the cornerstones of the idiosyncrasy of the order, namely the fight against infidels. ${ }^{66}$ Some papal bulls attributed rights to the military institutions to build churches and cemeteries in "unpopulated" places as well as in villas in the confines of Christianity in border regions with Muslims. Innocent III addressed the Hospitallers under these terms, echoing all pontifical tradition that had sustained this concession under Alexander III, Lucius III and Celestine III. ${ }^{67}$ Indeed, the Hospital also received authorisation to erect churches, cemeteries and oratories in lands occupied by the Muslims or in lands "which could be taken from the hands of the Saracens" ${ }^{68}$ Along the same lines, Honorius III ( 12 i 7 ) protected Hospitaller churches, cemeteries and houses in conquered Muslim lands, responding to the Master's and knights' petition. ${ }^{69} \mathrm{He}$ also empowered them to collect tithes and first fruits from these conquered regions. ${ }^{70}$ With a similar aim, of restoring religious activity, Gregory IX empowered the Templars to build churches in lands taken from the Muslims except places that had been episcopal seats, re-

I 204, AHN, Órdenes Militares, San Juan de Jerusalén, carp. 594, no. I 5 and I 3 February I 208, AHN, Órdenes Militares, San Juan de Jerusalén, carp. 599, no. I9.

65 29 May I 7 I , ACA, Órdenes Religiosas Militares, Gran Priorato de Cataluña, carp. 6, no. I 79 : Nos A. et ego Guilelmus de Laurag et aliorum fratribus...Petri apostoli et romane ecclesie recolligimus uobis in nostra societate.

66 Celestine III praises the heroic actions of the Templars as defenders of the Church, 25 June I I 94 , see above (note i 9 ).

67 La documentación pontificia hasta Inocencio III, ed. Mansilla, no. 358.

68 Honorius III to the Hospitallers, 3 December I 2 6, AHN, Órdenes Militares, San Juan de Jerusalén, L.649, fol. 3, no. 3 (I 2 I 6) and another similar from Gregory IX, 5 December I 229, fol. 8, no. I 4 and I i May I 236, fol. Io, no. I 8 .

69 Documentación pontificia de Honorio III (I2I6-I227), ed. Demetrio Mansilla (Roma: Instituto Espanol de Historia Eclesiástica I 965), no. 23 and similarly no. 25 for Temple.

70 Ibid., no. 40. 
capitulating previous papal interventions. ${ }^{71}$ This was justified because it was per la deffensio de la cristiandat, which reflected the ecumenical identification of the ecclesial restoration entrusted to the orders.

In some way, guidelines were applied to the organisation of the Church in conquered lands, in line with those of a political or military nature. It could be said that these authorisations were rights to conquer, but they were particularly the result of strategies aimed at guaranteeing occupational success. The pioneer church was linked to pontifical authority given that it was not subject to any other prelate. The papacy conceived that the re-Christianisation of said conquered areas was related to the orders' mission, thus combining religious or spiritual activity to military, derived from its direct power. ${ }^{72}$

Despite the fact that it was an ecclesiastic measure, the definition of the new ecclesial map in conquered lands was related to forming political realities. In fact, one Templar codex included a copy of a ro95 papal bull, possibly reconstructed or falsified, in which Urban II granted the King of Aragon, Pedro I, the right to "give, aggregate and divide churches in the villages conquered by the Moors" and "those built in his kingdom from which he could retain their tithes and first fruits". ${ }^{73}$ Irrespective of its veracity, the record placed the church of conquered areas under the authority of the political powers. This approach must have provided justification for the special definition the Church had in those areas, especially considering that the main political powers were responsible for designing the remaining jurisdictions in conquered lands and attributed a primary role to the orders. In confirming the Templars' rights to the Monzón church in I I 5 I, negotiated with the Bishop of Lleida, Eugene III specified that it had been resolved in the presence of

${ }^{71} 7$ October [ I 227/I 24 I], AHN, Órdenes Militares, San Juan de Jerusalén, L.598, fol. I 0 and I I, no. I 3 , and 7 October [1 227/I 241], AHN, Órdenes Militares, San Juan de Jerusalén, L.597, fol. i 48 , no. i i 4 .

72 Innocent III to the Templars, 8 September [ I I 98 / I 2 I 6], AHN, Órdenes Militares, San Juan de Jerusalén, L.597, fol. 68-69, no. 37 (Temple) and 3 December I 2 16, AHN, Órdenes Militares, San Juan de Jerusalén, L.649, fol. 3, no. 3 (Hospital). Similar bulls given by other popes: AHN, Órdenes Militares, San Juan de Jerusalén, L.649, fol. r o, no. I 8 (Hospital); and AHN, Órdenes Militares, San Juan de Jerusalén, carp. 85 I , no. 33 (Hospital). Also in Les archives, ed. Delaville, no. 5 I ( 1217 ). The links with the pope and his protection in this mission were expressed in other letters: Honorius III confirms the privilege of Innocent III and Alexander III given to the knights of the Temple, so that neither they nor their subjects can be excommunicated by any ecclesiastical authority, unless the Pope, 3-4 December I 2 19, AHN, Órdenes Militares, San Juan de Jerusalén, carp. 85 I, no. 24, 25 and 26; and Gregory IX grants the Hospitallers to have churches on conquered lands, 5 December I229, AHN, Órdenes Militares, San Juan de Jerusalén, carp. 595, no. 33, and I I May I 234, no. 34.

73 April ı 095, AHN, Órdenes Militares, San Juan de Jerusalén, L.597, fol. I 2 I - I 2 5, no. 87. 
the Count of Barcelona, Ramón Berenguer IV. ${ }^{74}$ This is an example of the importance of the inclusion of political powers by papal authority, evident years later in the confirmation of Adrian IV (I I 57).75

As mentioned, the pontiff associated obtaining assets in Aragon and Catalonia to the merit of the Templars in defending the Western Church. The vindication of crusader roles referred especially to the Holy Land rather than similar peninsular scenarios, and in this context, it is worth highlighting the papacy's defence of the receipt of subsidies there. Several papal missives were issued in defence of collecting what was known as "alms", which represented a danger for the Templars given that they acted per defensio de la crestiandat continuament en les partides de la mar..$^{76}$ Accordingly, Innocent IV, Alexander IV and Clement IV exempted the order of the Temple from contributions to the ecclesiastic tax system in I 248, I 259 and 1265 , respectively, due to their participation in the "war in the Holy Land". ${ }^{7}$ The papacy thus identified the institution as its armed force, especially in defence of the Holy Land, exempting them from the payment of duties imposed by various ecclesial authorities to meet their military obligations overseas. The papal letters claiming the "alms" reveal the aim of preventing or correcting diocesan meddling as was recorded in Navarre in relation to both orders. ${ }^{7}$ Likewise, in I I 84 , the pope defended donations of weapons and horses from those buried in the Hospital in view of withholdings undertaken by members of the Church ranks. In fact, he indicated that they could not withhold such arsenal given that it was used to defend

74 is March i I 5 I, AHN, Órdenes Militares, San Juan de Jerusalén, L. 597 , fol. I I 4, no. 77.

75 Les archives, ed. Delaville, 4 I O-4 I I nos. 58 and 59, and also Delaville Le Roulx, "Bulles," 4 8 -4 I 9 (Source edition no. I 5 , Célestin III confirme aux Templiers la possession de l'église S. Jean de Monzon).

${ }_{76}$ Gregory IX to archbishops, bishops and ecclesiastics in favour of the Templars, 26 November I 227, AHN, Órdenes Militares, San Juan de Jerusalén, L.598, fol. I I- I 2, no. I 4.

77 For the bulls of Innocent IV, see: El Gran Priorato de Navarra, 2, ed. García Larragueta, no. 3 I 9 and La documentación, ed. Quintana Prieto, no. 5 I 3 : considerantes quod dilecte fratres Hospitalis Jerosolimitani memorate succursus Terre institunt continue pro ipsius defensione, indefesso brachio decertantes ( I 248). For Alexander IV: I 6 February I 259, AHN, Órdenes Militares, San Juan de Jerusalén, L.598, fol. 20, no. 20: a la ajuda de la Terra Santa en tota manera (1259), and for Clement IV: I 8 May I 265, AHN, Órdenes Militares, San Juan de Jerusalén, L. 598, fol. 3, no. 3.

78 For the Temple: Honorius III to the prelates, I 2 January I 2 I 8, AHN, Órdenes Militares, San Juan de Jerusalén, L.649, fol. 6-7, no. I 2 and Honorius III orders that the knights should not be impeded from burying their brothers and receiving the alms that are collected in their churches, and the indulgences granted by their predecessors, I 6 January I 2 1 7, AHN, Órdenes Militares, San Juan de Jerusalén, carp. 852 , no. 2 r. For the Hospital: Alexander III orders the ecclesiastical authorities not to allow certain priests to prevent the collection of alms in favour of the Hospital, is May [ I I 59/ I I 8 I ], see above (note 40). 
the Holy Land. ${ }^{79}$ Nonetheless and despite the needs and realities of the Peninsula, the pontiff defended the orders in their mission in eastern lands and in the context of their participation in crusader states.

\subsection{Pontifical defense in view of the resistance of the diocesan powers towards Templars and Hospitallers: On the right of excommunication and interdict}

The entry of the Temple and Hospital in the ecclesial organisation created tensions and disputes with ecclesiastic dignitaries, and the papacy arbitrated solutions which were quite often in defence of the orders. The recurrence and severity of the conflicts and pontifical actions reflect the intensity of resistance by the diocesan ecclesiastic institutions. Papal sources reflect the scope of opposition or differences among the ecclesiastic powers in relation to the military institutions. Bishops and, occasionally, abbots and other authorities would take action against their people, property and rights, sometimes even radically. Episodes of excommunication and interdicts against the orders and their churches show how they were the object of harsh accusations and repression by these prelates. The papacy prohibited other members of the Church from issuing any interdicts against the Templar and Hospitaller churches as was done by Alexander III, Innocent III $^{80}$ and confirmed by Honorius III in $1219,{ }^{81}$ who recalled it was a jurisdiction reserved for the pontiff. ${ }^{82}$ Several bulls and letters by Alexander IV (I254-I26I) and Urban IV ( I 26 I-I 264), translated to Catalan and compiled in a cartulary gave details of the Templars' dependence on the pope in matters referring to excommunication

79 I 2 December I I 84, AHN, Órdenes Militares, San Juan de Jerusalén, carp. 594, no. 5.

80 One of the first interventions against excommunication of the Hospitallers and the imposition of the interdict on his oratories was made by Alexander III: Alexander III orders the ecclesiastical authorities to allow the quaestors of the Hospital of St. John of Jerusalem to publish the confraternities of the order and to beg for alms, 2 March [ I I 59/ I I 8 I ], see above (note 36).

8I AHN, Órdenes Militares, San Juan de Jerusalén, carp. 852, no. 25 and no. 26: this recalls previous privileges granted by Innocent III, Alexander III. Honorius III vetoed the diocesans to excommunicate Hospitallers and Templars, as was recorded once again in their respective cartularies: AHN, Órdenes Militares, San Juan de Jerusalén, L.649, fol. 2, no. I; cf. 2 I January I 22 I, AHN, Órdenes Militares, San Juan de Jerusalén, L.597, fol. 97, no. I6, and also L.598, fol. 20-2 I, no. 2 I. These remembered and renewed previous bulls: Innocent III to the prelates, 4 September I 209, AHN, Órdenes Militares, San Juan de Jerusalén, carp. 594, no. 22. In I 202, the same pontiff, Innocent III, had prohibited the bishops from fining Hospitallers accused of moral vices and reminded them that they should be judged by people of the order, 27 May I 202, AHN, Órdenes Militares, San Juan de Jerusalén, carp. 594, no. I 4.

82 Honorius III to prelates, I 3 February I 2 I 7 , AHN, Órdenes Militares, San Juan de Jerusalén, L.649, fol. 6-7, no. I 2 and I 3 December I 2 I 6, AHN, Órdenes Militares, San Juan de Jerusalén, fol. 2, no. I (Hospital); and AHN, Órdenes Militares, San Juan de Jerusalén, L.598, fol. 20-2 I, no. 2 I (Temple). 
and interdict, and never on the diocesan. ${ }^{83}$ This pontifical authority also inferred the power to excommunicate those who attacked the assets of members of the order, as mentioned in a papal missive by Alexander IV at the request of the Templars. It further insisted that Templars were under papal protection. Other actions by Alexander IV opposed interdict actions against Templars by ecclesiastic authorities and by the Patriarch of Jerusalem. ${ }^{84}$

These rules were recalled and recovered when circumstances so required. Thus, a I 294 papal intervention addressed to the Bishop of Tortosa reminded him that the excommunication of Hospital members and their families was his own prerogative and rightfully replicated a papal bull by Alexander IV. This missive was copied in the Hospital's Cartulario Magno along with others related to this same matter. ${ }^{85}$ Both military orders upheld their exclusive dependence on the papacy with regard to matters related to compliance with religious obligations by their members, and even family members, as can be deduced from the systematisation of these papal documents in their codices. In all, some papal excommunications permitted actions by the diocesan powers such as when Clement IV authorised prelates and abbots to excommunicate anyone who took refuge in the house of the Templars. ${ }^{86}$

Radical interventions against Templars and Hospitallers by some ecclesiastic powers and even laypeople were reprimanded by the papacy, which deployed punitive strategies to prevent actions against the orders' assets and people. Alexander III ordered the ecclesiastic authorities to punish those who disturbed, mistreated and stole from the Hospitallers. ${ }^{87}$ Sometimes, the pontiff would threaten those who invaded their property with excommunication. ${ }^{88}$ The pope even urged prel-

83 Alexander IV to the Templars, 23 August [ I 254/ I 26 I], AHN, Órdenes Militares, San Juan de Jerusalén, L. 597, fol. 46-48, no. 25; Alexander IV to the Templars, 5 March 5 I 25 5, fol. 48-49, no. 26; Alexander IV to the Templars, 5 March I 257, fol. 49-50, no. 27; Urban IV to the Templars, February I 262, fol. I 27-I 28, no. 90, etc.

84 Alexander IV to the Templars, 29 February I 256, AHN, Órdenes Militares, San Juan de Jerusalén, L.597, fol. 52-53, no. 29.

85 Alexander IV to the prelates, 2 I September I 294, AHN, Órdenes Militares, San Juan de Jerusalén, L.649, fol. 26, no. 36. Other papal bulls addressed to some other prelates were also recorded in this cartulary, AHN, Órdenes Militares, San Juan de Jerusalén, fol. 2 I -22, no. 3 I and others related to some actions of bishops against Hospitallers, AHN, Órdenes Militares, San Juan de Jerusalén, fol. 22, no. 32, etc.

863 I May I 265, AHN, Órdenes Militares, San Juan de Jerusalén, L.598, fol. 5, no. 6.

872 March [I I 59-I I 8 I], see above (note 36).

88 Several bulls followed one another with these contents referred to the Hospital, and it was pointed out that their members had been object of violence, such as the ones from i I 66, I I 67, I 68 and I I 79, Les archives, ed. Delaville, nos. 49 and 50 (I I 84). Some other bulls along these lines: The bull of Innocent III , I 4 February I 208, AHN, Órdenes Militares, San Juan de Jeru- 
ates and abbots to excommunicate anyone who attacked the Templars and who had retained their property. ${ }^{89}$ Innocent III was particularly active in denouncing abuses committed against the Knights Templar and imposing solutions, complaining of the mistreatment of the Templars by laypeople and ecclesiastics. ${ }^{90}$

\subsection{Pontifical defence in the face of actions taken against the orders}

Actions against the orders' assets were reprimanded by the papacy from early on. Eugene III authorised the Hospitaller master so that knights could recover any property that had been taken from them for whatever reason, and these provisions were confirmed by other popes. ${ }^{91}$ These interventions were used to defend their assets at other times..$^{92}$ On occasions, papal actions were aimed at correcting abuses committed by other powers, even against kings. It was along these lines that Innocent III ordered the Bishop of Tarazona to admonish King of Navarre, Sancho VII, the Strong, so that he would return the property that had been taken from the Templars. ${ }^{93} \mathrm{He}$ also urged the same bishop of Tarazona and the Bishop of Zaragoza to return of the castle that G. Ortiz had stolen from the Templars, and to apply ecclesiastic censorship. ${ }^{94}$

Templars, Hospitallers and the representatives of the episcopal seats were at the centre of many disputes due to the ecclesiastic prerogatives such as those which occurred in relation to the orders' rights to found oratories and cemeteries. Eugene III defended the Templars' rights against the prelates and abbots to build or-

salén, L.649, fol. 50-5 1, no. 72; cf. fol. 8, no. I 3. Some similar measures in defence of Temple's patrimony: Innocent III to the Master of the Temple, July I 206, AHN, Órdenes Militares, San Juan de Jerusalén, L.597, fol. 62-64, no. 32 and Innocent III to the prelates, I 3 December [ I 198/ I 2 16], AHN, Órdenes Militares, San Juan de Jerusalén, fol. 96-97, no. 60; cf. AHN, Órdenes Militares, San Juan de Jerusalén, carp. 852, no. 24 and 27. Some confirmations in defence of Hospitallers' rights: AHN, Órdenes Militares, San Juan de Jerusalén, carp. 852 , no. $33,35,36,37,40,89$ and 91 .

89 La documentación pontificia hasta Inocencio III, ed. Mansilla, nos. I 97 and 236 ( I 200).

90 Innocent III, addressing all the bishops and prelates of the Church, he complains about the bad treatment given to the Templars, December I I, I I 99, see above (note 22); Innocent III addressing all the bishops and prelates of the Church, he complains about the bad treatment given to the Hospitallers, January 25, I 206, see above (note 22). In I 204, Innocent III denounced, for example, that the bishops were persecuting the Temple, io June i 204, AHN, Órdenes Militares, San Juan de Jerusalén, L.597, fol. 86-7, no. 53.

91 Cartulaire général, I, ed. Delaville, no. 2 I 7.

92 See above (note 57).

93 La documentación pontificia hasta Inocencio III, ed. Mansilla, no. 255 ( I 20 I).

94 Innocent III orders to the bishops of Zaragoza and Tarazona to force G. Ortiz to return to the knights of Temple a thousand sheep and goats that he had stolen, 6 June I 20 I, AHN, Órdenes Militares, San Juan de Jerusalén, carp. 85 I, no. I 4. 
atories and have cemeteries for themselves and their servants within their jurisdiction. ${ }^{95}$ In fact, there are testimonies of bishops opposing said prerogatives, such as the bishop from Lleida, who actively resisted the burial of a knight in the order's cemetery until pope Alexander III intervened in favour of said burial, recalling that Hospitallers possessed such right. ${ }^{96}$ Moreover, the Hospitallers were authorised by Lucius III in I I 83 , to bury members of the brotherhood in their churches and receive offerings for their deceased, yet their cemeteries had to be blessed by the bishops. ${ }^{97}$ Similar privileges were confirmed and outlined by Celestine III ( I I 94) and Honorius ( I 2 I 7 ), such as those permitting the order of the Temple to use priests and clerks for their own services and to build oratories and cemeteries. ${ }^{98}$ The right of burial was particularly claimed and a subject of interest to the orders. This would explain how a document on the right of Templars' burial in Sicily and Italy by Innocent III was transferred to the Navarrese collections in the I 6th century. It was seemingly a remote situation but continued to be useful and of interest to Navarrese Hospitaller communities centuries later. ${ }^{99}$ Other pontifical stipulations on who was to be buried in the orders' cemeteries aimed to ensure the benefits associated with the choice of said burials by laypeople, whether for spiritual or economic reasons. ${ }^{100}$ The bishops and other ecclesiastic authorities were thus reminded and required when Honorius III ordered not to hinder ecclesiastic burial of Templar brothers or prevent the questioning of alms in the churches in 1217 . He recalled that said rights had been granted by his predecessors. ${ }^{101}$

95 I I 46-I I 49, AHN, Órdenes Militares, San Juan de Jerusalén, L.597, fol. I I 4-i I 5, no. 78.

96 Diplomatari d'Alguaire i del seu monestir santjoanista de Io76 a I244, ed. Jesús Alturo i Perucho (Barcelona: Fundación Noguera, I 999), no. I 4 ( I I 64).

97 Lucius III to the Hospitallers, October i I 83, AGN, Clero, Desamortizados, Convento de sanjuanistas de Puente la Reina, no. 36 , fol. I 4 v.

98 Celestine III praises the heroic actions of the Templars as defenders of the Church, 25 June I I 94, see above (note 19) and Eugene III, exhorts Christians to help the Templars and integrate into their brotherhoods, I 3 November I I 46/ I I 49, see above (note 24).

99 Innocent III allows the Templars of southern Italy and Sicily the right to burial, without the bishops being able to demand a quarter of the alms, is March i I99, AGN, Clero, Desamortizados, Convento de sanjuanistas de Puente la Reina, no. 36 , fol. 32 v. Copy from i 6th century (I I 99).

${ }_{100}$ For the spiritual benefits related to the Templars see, Alan John Forey, The Templars in the "Corona de Aragón" (London: Oxford University Press, I 973), I 62-163; and some bulls reminded Hospitallers' rights related to burials to the prelates: 25 April I i 84, AHN, Órdenes Militares, San Juan de Jerusalén, carp. 594, no. 4 and no. I 2; December I I 84, AHN, Órdenes Militares, San Juan de Jerusalén, carp. 594, no. 5; Innocent III, 23 January I 207, AHN, Órdenes Militares, San Juan de Jerusalén, carp. 594, no. io and no. I7; and Honorius III to the Hospitallers, 3 January I 2 I 7 , AHN, Órdenes Militares, San Juan de Jerusalén, carp. 595, no. 3 I.

ror Honorius III orders that the knights should not be impeded from burying their brothers and receiving the alms that are collected in their churches, and the indulgences granted by their 


\subsubsection{Affirmation of religious and ecclesiastic prerogatives of the orders in relation to diocesan powers}

Other measures complemented and often defended the rights of the orders relating to the burial of dependants and their relatives. A papal missive by Alexander IV, in response to demands from the Hospitallers, set forth that the brothers' wives and children should be buried and could not be rejected by other members of the Church, even those under interdict. ${ }^{102}$ Templars obtained similar protection given that priests and some prelates had prevented the entrance of the wives of Templar vassals such as those "who would go to thank God for the birth of a child". Some vassals were denied burial of their children on the pretext that their husbands had been excommunicated. ${ }^{103}$

Pontifical policy was to defend the orders with rights in oratories and cemeteries yet under a series of restrictions which gave preference to the burial of knights, members of the brotherhood and family members. Thus, the diocesans maintained prerogatives such as blessing these sites and even receiving tithes for burial in some cases. ${ }^{104}$ Some bishops did not wish to comply with these provisions; pope Innocent III ordered the Bishop of Huesca to bless the Templars' chapel and their cemetery, pursuant to the apostolic privileges granted to that institution. He was warned that if he did not comply with the mandate, the Bishop of Lleida would do so as commissioned. ${ }^{\text {os }}$ On the other hand, the new institutions took their rights beyond the expected scopes and some bishops protested such as those from Lleida and Tortosa against Alguaire commandery. Disputes arose after the Hospitallers had buried people who were not under their jurisdiction. In this situation, the papacy defended the diocesan and prohibited the Hospitallers from burying people who were not strictly dependent on them or under their direct jurisdiction. ${ }^{106}$

The celebration of mass and the provision of priests were also controversial issues with the diocesans, and the papacy reacted in defence of the rights of the orders. Several pontifical provisions, such as those by Alexander III in I I 63 and

predecessors, I 6 January I 2 I 7 , see above (note 78 ).

${ }_{102}$ Joaquim Miret i Sans, Les cases de Templers y Hospitalers en Catalunya (Barcelona: Casa de la Caritat, Barcelona, I 910 ), 34 I-342.

${ }_{103}$ Alexander III in favour of the Temple and his Master, I 8 June I I 63, AHN, Órdenes Militares, San Juan de Jerusalén, L.597, fol. 42-44, no. 2 I.

104 Alexander III in favour of the Temple and his Master, I August I I 59, AHN, Órdenes Militares, San Juan de Jerusalén, L.597, fol. I-9, no. I.

ros La documentación pontificia hasta Inocencio III, ed. Mansilla, no. 223 ( I 199).

${ }^{106}$ Diplomatari d'Alguaire, ed. Alturo i Perucho, no. 34 ( I I 74- I I 76). Innocent III banned Hospitallers to bury in prejudice of the Diocese of Tortosa's rights, Cartulaire général, I, ed. Delaville, no. 1079 ( I I 99), who also sent the bishop of Lleida and the abbot of Poblet, no. I 080. 
Celestine III in I 194, allowed the reception of ecclesiastics in Templar buildings to celebrate mass although they had to request permission from the bishops. ${ }^{107}$ However, Alexander III's papal bull indicated that they could be admitted even if the bishops did not give their consent. ${ }^{108}$ Some documents copied in codex 597 warned of the tensions created by the bishops' opposition to the orders having clergy for their churches; and how the popes would defend the Temple's prerogatives $^{109}$ and, similarly, those of the Hospital. ${ }^{110}$ Episcopal authorisation was sometimes given, as in the case of power over the church of Alguaire in $1239,{ }^{111}$ although in all reality a papal letter by Honorius III set forth that the bishops only held power over the Hospitaller churches that they had always had, as was customary. ${ }^{12}$ Actions in favour of religious spaces and services are very articulate because they are very eloquent because they framed acceptance of military orders as ecclesial institutions. However, given the competitiveness between roles, the diocesan authorities manifested opposition to the military orders, reflecting that they were less appropriate for the exercise and celebration of liturgical activities.

\subsection{The papacy and tensions between the orders and diocesan powers}

However, the tensions between the orders and the diocesans should not be interpreted simply as the result of the authority of power and control over ecclesial

${ }_{107}$ Celestine III praises the heroic actions of the Templars as defenders of the Church, 25 June I 194, see above (note 19). It also refers to the previous tradition: Alexandri, Luçii, Urbani et Clementis, romanorum pontifficium.

${ }_{108}$ Alexander III in favour of the Temple and his Master, I August I I 59, see above (no. I04). This solution confirmed previous ones arranged by the pontiffs Eugene III and Adrian IV, authorizing the Templars to have chaplains, who were not of the order, but who had the episcopal permission, Diplomatari d'Alguaire, ed. Alturo i Perucho, no. 62.

109 Innocent III to the prelates, 22 June [ I I 98 / I 2 I 6], AHN, Órdenes Militares, San Juan de Jerusalén, L.597, fol. 75-77, no. 43 and 23 June [I I $98 /$ I 2 I 6], fol. 79-80, no. 47.

I10 A bull of pope Alexander III ordered that: manda que los fratres del Espital puedan presentar a los diocesanos qualesquier personas ydoneas en sus eglesias, AHN, Órdenes Militares, San Juan de Jerusalén, L.649, fol. 23, no. 34. Other letters along these lines: I 3 April i i 6 I, L.649, fol. 9, no. I 6; fol. 22, no. 33; and fol. 23, no. 34. It was even allowed by the pope Gregory IX that Hospitallers in Spain could present to the bishop lay people who lived in their houses to guarantee the religious services, I 3 April I 234, AHN, Órdenes Militares. San Juan de Jerusalén, carp. 595 , no. 36; and also Vidimus made by Pedro de Albalate, archbishop of Tarragona from the former privilege given by Gregory IX, 9 January I 24 I , AHN, Órdenes Militares. San Juan de Jerusalén, carp. 595 , no. 36 .

in Diplomatari d'Alguaire, ed. Alturo i Perucho, no. 322.

${ }_{112}$ Honorius III to the prelates, I 2 May I 225, AHN, Órdenes Militares, San Juan de Jerusalén, L.649, fol. 6, no. I I: manda que los prelados no ayan en las eglesias del Espital sino solament la procuracio si aquella ouieron acostumbrado recebir. 
activities. The eruption of new institutions certainly caused some dysfunction in relations with previously well-established ecclesial governments; as suggested in a pair of pontifical missives by Innocent III in I 198 . One was addressed to the commander of Amposta, prohibiting him from burying and administering the sacraments to the residents of Tortosa who were interdicted for not offering their tithes and first fruits. All available evidence indicates that the locals had taken advantage of the fact that the Hospitallers had a church in the city. Consequently, the knights attracted those who had been left outside the church, against the interests and responsibilities of the Bishop of Tortosa, who had made the request. ${ }^{113}$ This situation was of such importance that the pope himself sent another letter to the Bishop of Lleida and Abbot of Poblet to force the commander to fulfil said demand. ${ }^{114}$ Years later in 1207 , the pope sent another missive to the same residents to obey the Bishop and Church of Tortosa. He reminded them that they had attempted to bury about a hundred corpses in the Hospital church cemetery even though they had been excommunicated for not paying the ecclesiastic rents. The ruling even provided for disinterring the excommunicated dead. ${ }^{115}$

Diocesan interference and complaints against the orders were particularly relevant to the payment of tithes and first fruits, which led to heated debates between the seats and said institutions. ${ }^{116}$ However, the popes took little action on specific matters and their relations were above all general in scope such as exempting lands directly farmed by the Templars from tithes, as was also done by Innocent III and

\footnotetext{
I1 La documentación pontificia hasta Inocencio III, ed. Mansilla, no. I 36.

14 Ibid., no. I 37.

is Ibid., no. 396.
}

I 6 Bernardo, bishop of Zaragoza, and Pedro de la Rovira, master of the Temple, agree on the model of perception of the tithes related to the order's lands, I 5 July i I 47, AHN, Órdenes Militares, San Juan de Jerusalén, L.595, fol. 3 r, no. 6 and fol. 26 v-27 r, no. 7 I ; Miguel, Bishop of Tarazona, donated to the Temple, the fourth part of the tithes of the church of Ambel, which he had retained for himself in the donation made previously, 9 February i I 48, L.595, fol. I 36 v-I 37 r, no. 34I, and AHN, Órdenes Militares, San Juan de Jerusalén, carp. 628, no. 5. Accordance between the Temple, the prior and the chapter of Santa María de Tudela, on the rights of the Ribaforada church, I I 93, AGN, Códice I, fol. 207-208; Celestine III confirms an agreement between the Templars of Ribaforada and the council of Tudela, 26 March i 196, Tudela, Archivo Diocesano de Tudela, fajo D, no. 3 I (I I 96, I 22 I, I 232, I 240, I 246); The archbishop of Tarragona, Ramón de Rocabertí, resolves the lawsuit between the chapter of Santa María de Tudela and the order of the Temple, 8 April i 204, Tudela, Archivo Diocesano de Tudela, fajo P. Q. R., no. 9 ( ( 204), etc. See also for more examples and details these studies: Forey, The Templars, I68-I7 I; Laureà Pagarolas, La comanda del Temple de Tortosa: primer periode (II48-I2I3) (Tortosa: Dertosa, I 984), I 34-I 38, and Bonet, La orden, 286-287. 
Honorius III. ${ }^{17}$ On the other hand, the latter pontiff ordered prelates to excommunicate anyone who demanded the tithe from Templars on their lands. ${ }^{118}$ The popes chose to offer mediators instead of directly solving the problems. ${ }^{19}$ To this end, the pope entrusted other ecclesiastic authorities with resolving conflicts between ecclesiastic institutions, for example, the conflicts confronting the Templars and the Abbot of Alaón. The Abbot of Ripoll was chosen to establish the rights in certain churches. ${ }^{120}$ The documental collections and codices of the orders included papal bulls which legitimised their rights to said ecclesiastic rents ${ }^{121}$ and, as a result, limited the bishop's aspirations and demands. ${ }^{122}$ Pontifical restrictions on the collection of ecclesiastic taxes even prevented the Apostolic legates from being able to receive the one-fourth, one-fifth, one-tenth and one-twentieth duties in Aragon, Catalonia and Hispania in $1249 .{ }^{\mathrm{I} 23}$ At other times, the pontiff made use of diocesan powers to enforce the orders' privileges and rights to duties. In fact, Innocent III required the Archbishop of Tarragona to enforce a testamentary disposition and the payment of revenue to which the Templars had a right. ${ }^{24}$ Other papal measures were aimed at preventing diocesan powers from imposing fines or monetary penalties on the orders. ${ }^{125}$

${ }_{117}$ At the request of Juan de Beaumont, prior of Navarre, was made a vidimus of papal privileges granted to the Order of Saint John, I 5 June I 442, AHN, Órdenes Militares, San Juan de Jerusalén, carp. 855, no. 89. Documentación pontificia de Honorio III, ed. Mansilla, no. 36 ( I 2 I 7 ). Honorius ordered bishops and abbots not to defraud Templars' tithes in specific cases such as the lands they cultivated directly.

${ }^{118}$ La documentación pontificia hasta Inocencio III, ed. Mansilla, no. I 97.

119 Ibid., no. 532 (1 216).

${ }_{120}$ Ibid., no. 259. Occasionally the king took part in sorting out problems such as the division of the tithes, Diplomatari del Masdéu, vol. III, ed. Rodrigue,Tretón (Barcelona, Fundació Noguera. 2010), no. I60 (II95).

${ }_{121} 2$ I June I 232, AHN, Órdenes Militares, San Juan de Jerusalén, L.649, fol. 8-9, no. I 5 ; fol. 40, no. 35; AHN, Órdenes Militares, San Juan de Jerusalén, carp. 598, no. I07, and Innocent IV confirms privileges given by his predecessors to the Hospitallers referred to the exemptions of the tithes, 20 November I 248, AHN, Órdenes Militares, San Juan de Jerusalén, carp. 595, no. 39.

${ }_{122}$ Innocent IV confirms tithes to the Hospitallers, addressing the letter to the prelates, I 3 November I 246, AHN, Órdenes Militares, San Juan de Jerusalén, carp. 595, no. 38. Specific matters also involved the papal intervention in favor of the order, as a provision addressed to the Archbishop of Tarragona in relation to the tithes, I 3 November [I I 84/ I I 85], AHN, Órdenes Militares, San Juan de Jerusalén, carp. 594, no. 8.

123 Innocent IV to the Hospitallers, I I August I 249, AHN, Órdenes Militares, San Juan de Jerusalén, carp. 595, no. 40.

${ }^{124}$ La documentación pontificia hasta Inocencio III, ed. Mansilla, no. 235 ( I 200)

125 Innocent III bans ecclesiastics to fine the Hospitallers, 3 February I 207, AHN, Órdenes Militares, San Juan de Jerusalén, carp. 594, no. I 8. 


\section{FinAL THOUghtS}

Pontifical action in favour of the Temple and the Hospital was fundamental to their initial development, not only overseas, as part of the Crusader context, but also in Western Europe. Up until the beginning of the $\mathrm{s} 2$ th century, no institution founded to serve Christianity had received such unconditional and recurrent support from Rome. The situation of conflict in Crusader states and the ecclesiastical institutional reconstruction gave the papacy a new role as mediator and leader of the situation beyond a "propagandistic" image. The interest in controlling and centralising the administration of a changing Church led to an increase in diplomatic activity by the Roman offices but also to a new ecclesiology in which the papacy attributed a prominent role to the Templars and Hospitallers.

A number of affairs related to hierarchical organisation, discipline, liturgy, modification of rights and others were managed from the papal seat, which was often itinerant. Military orders, such as the Temple and the Hospital, were subject to actions by popes who were not interested in them merely as another part of their structure. Their very essence, based on militant charisma towards enemies of the faith, and their caring charisma towards pilgrims (of biblical roots) as well as the complex circumstances of their origin and initial development meant they would incardinate perfectly into the pontifical plan. Thus the Bishop of Rome became the primary protector of some institutions that were called to maintain the reformist spirit in Europe, reflected in the fight against the Muslims in the Holy Land, made up of knights who indirectly were the ideal role-players in the new ecclesiology. On a theoretical level, the pope essentially influenced the defence of the overseas functions of both orders, also in the messages sent to Hispanic priories, although he occasionally supported their participation in military actions in the expansion of the Peninsula. The Aragonese and Catalan friars were especially commissioned to undertake the restoration of the church in those places reconquered from Muslim hands.

Of the various popes, Eugene III, Alexander III and Innocent III were particularly active in promoting the orders at crucial and critical times in the development of the crusading movement in the East and, coincidentally, during the deployment and consolidation of the lands in the northern third of Hispania. However, in the cases of prominent and insistent actions by popes Alexander III and Innocent III it is worth mentioning that the arrival of their missives coincided with periods of inactivity and difficulties in the expansion of Christianity as well as the reconfiguration and settlement of both orders in determined spheres in Aragon, Catalonia and Navarre. It is possible to establish a correlation between the general reformist momentum promoted by these popes with their policies aimed at consolidating 
both orders as agents of their reform programmes and reactivation of the crusades, as well as key agents in the new ecclesiology which pivoted around the pope. In general, the popes were active in defending the role of the orders, of their dependence in relation to the See of Rome and on matters relating to excommunication, but did not directly get involved in many of the conflicts with diocesan powers, except for those affirming specific rights of the ecclesiastical ministry of the friars. On the other hand, and no less important, the Templars and Hospitallers in the northern third of the peninsula demanded this special and privileged dependence over the centuries, something which became an unequivocal mark of their identity and their charisma.

Nevertheless, like other realities and groups founded to serve the Church, their early years and later development were not without problems. Their international nature and exemption with respect to local ecclesiastical authorities led to disjointedness as well as conflicts. So, to keep these institutions as well as the ecclesial reality functioning properly the popes would issue stipulations which anticipated, interpreted or resolved problems for two reasons: firstly, they would ratify their protection of Templars and Hospitallers and, secondly, their presence in the form of papal bulls would ratify their reformist plans towards restoring the centralisation and authority of Rome. Hence, with the combined collections from Aragon, Catalonia and Navarre, the members of the orders very quickly had the necessary tools to maintain the written stipulations which guaranteed their normal development and emphasized their dependence on the highest religious authority in the West.

The mode of preservation, number and typology of pontifical documents conserved, among the collections of these orders during the Middle Ages and in modern times, ultimately reveal that the construction of the memory of these institutions went beyond the logic of merely preserving the written word. The copies made in the 14 th, I 5 th and 16 th centuries as well as the elaboration of the Cartulario Magno, by Juan Fernandez de Heredia, indicate that the Hospitaller institution, recipient of the written legacy of the Temple, knew how to manage the distinct functionalities which the texts might have over time by selecting and rescuing a large part of the papal directives leading to the ratification of some of their historic rights. Hence, the analysis of the written pontifical legacy in these Hispanic priories opens a door to the use and contexts of the validity of what is graphical, acknowledging the problems of regional development of both orders, within the context of the regional powers. 


\section{PRIMARY SOURCES:}

Barcelona. Archivo de la Corona de Aragón, Gran Priorato de Cataluña, carp. 6 and 7, vol. I I I I.

Barcelona. Archivo de la Corona de Aragón, Registros de Cancillería, no. 309 and 3 ro.

Madrid, Archivo Histórico Nacional, Órdenes Militares, L.597, L.597B, L.598, L.649, L.659 and L.662.

Madrid. Archivo Histórico Nacional, Órdenes Militares, San Juan de Jerusalén, carp. 594, $595,598,599,600,628,851,852,853,855,910$.

Pamplona. Archivo General de Navarra. Clero, Desamortizados, Convento de sanjuanistas de Puente la Reina, nos. 36, I 60, I 6 I and I63.

Pamplona, Archivo General de Navarra, Códice I.

Tudela. Archivo Diocesano de Tudela, fajo D and fajo P.Q.R.

Les archives de l'ordre de l'Hôpital dans la Péninsule Ibérique. Edited by Joseph Delaville Le Roulx. París: Ernest Leroux, i 893.

Carrasco Pérez, Juan. "Bulas Sanjuanistas del Gran Priorato de Navarra ( I I I 3 - I 3 I 2 ).” Anuario de Estudios Medievales, no. I I ( 98 I ): 523-530 (Source edition no. I 4, Honorio III ordena a la jerarquía recibir benignamente a los Hospitalarios que fuesen presentados como idóneos).

Cartulaire de Trinquetaille. Edited by Paul-Antonin Amargier and Aix: Centre d'Études des sociétés méditerranéennes. Publications universitaires des Lettres et Sciences $\mathrm{Hu}-$ maines d'Aix-en-Provence. Aix-en-Provence: Publications universitaires des Lettres et Sciences Humaines d'Aix-en-Provence, 1972.

Cartulaire du prieuré de Saint-Gilles de l'Hôpital de Saint-Jean de Jérusalem (II20-I210). Edited by Daniel Le Blévec and Alain Venturini. Turnhout-Paris: Brepols, 1997.

Cartulaire et chartes de la commanderie de l'Hôpital de Saint-Jean de Jérusalem d'Avignon au temps de la commune (II70-I250). Edited by Claude-France Hollard. Documents, études et répertoires publiés par l'Institut de recherche et d'histoire des textes 63 . Paris: CNRS Éditions, $200 \mathrm{I}$.

Cartulaire général de l'Ordre des Hospitaliers de S. Jean de Jérusalem (II00-I3IO). Vol. I, II00-I200. Edited by Joseph Delaville Le Roulx. Paris: Ernest Leroux, I 894.

Cartulaire général de l'Ordre des Hospitaliers de S. Jean de Jérusalem (II00-I3IO). Vol. 2, I20I-I260. Edited by Joseph Delaville Le Roulx. Paris: Ernest Leroux, I 897.

Cartulaire général de l'Ordre du Temple I I g?-I I so: recueil des Chartes et des Bulles relatives à l'Ordre du Temple formépar le Marquis d'Albon. Edited by Guigues Alexis Marie Joseph André d'Albon. Paris: Honoré Champion, i 9 I 3.

Delaville Le Roulx, Joseph. "Bulles pour l'ordre du Temple tirées des archives de S. Gervasio de Cassolas." Revue de l'Orient Latin, no. i I (1905-1908): 407-408 (Source edition no. I, Eugène III confirme, en les énumérant, les possessions données a l’ordre du Temple par Raymond-Bérenger III, comte de Barcelone).

Delaville Le Roulx, Joseph. "Bulles pour l'ordre du Temple tirées des archives de S. Gervasio de Cassolas." Revue de l'Orient Latin, no. I I (I 905-1908): 4I3-4I7 (Source 
edition no. I I, Alexandre III prend les Templiers d'Espagne sous sa protection, et confirme, en les énumérant, les donations qui leur avaient été faites).

Delaville Le Roulx, Joseph. "Bulles pour l'ordre du Temple tirées des archives de S. Gervasio de Cassolas." Revue de l'Orient Latin, no. i i (I 905-I 908): 4 I 8 (Source edition no. I4, Lucius III engage les prélats à exhorter les fidéles à faire des quétes pour les Templiers $[\ldots])$.

Delaville Le Roulx, Joseph. "Bulles pour l'ordre du Temple tirées des archives de S. Gervasio de Cassolas." Revue de l'Orient Latin, no. i I (1905-1908): 4 I 8-4I9 (Source edition no. I 5 , Célestin III confirme aux Templiers la possession de l'église S. Jean de Monzon).

Delaville Le Roulx, Joseph. "Bulles pour l'ordre du Temple tirées des archives de S. Gervasio de Cassolas." Revue de l'Orient Latin, no. I I (1905-1908): 4 I 9 (Source edition no. I6, Innocent III ordonne aux prélats de faire observer les priviléges des Templiers en matière de sépulture).

Delaville Le Roulx, Joseph. "Bulles pour l'ordre du Temple tirées des archives de S. Gervasio de Cassolas." Revue de l'Orient Latin, no. I I (I 905-1908): 42 I (Source edition no. 22, Innocent III ordonne aux prélats de protéger les biens et les priviléges des Templiers contre les usurpateurs, et d'excommunier quiconque ne se soumettra pas à leurs injonctions).

Delaville Le Roulx, Joseph. "Bulles pour l'ordre du Temple tirées des archives de S. Gervasio de Cassolas." Revue de l'Orient Latin, no. I I (1 905-1 908): 422 (Source edition no. 25, Grégoire IX ordonne aux prélats de faire rendre justice aux Templiers molestés par les paroissiens desdits prélats).

Delaville Le Roulx, Joseph. "Bulles pour l'ordre du Temple tirées des archives de S. Gervasio de Cassolas." Revue de l'Orient Latin, no. I I (1 905-1 908): 423 (Source edition no. 26, Grégoire IX défend aux prélats de faire condemner par les officialités les Templiers à des peines pécuniaires).

Delaville Le Roulx, Joseph. "Bulles pour l'ordre du Temple tirées des archives de S. Gervasio de Cassolas." Revue de l'Orient Latin, no. I I (1905-1908): 423 (Source edition no. 27 , Innocent IV ordonne à l'éveque, au sacristain et à l'archidiacre d'Huesca de mettre un terme aux incursions de divers seigneurs sur les biens du Temple dans le diocèse d'Huesca).

Delaville Le Roulx, Joseph. "Bulles pour l'ordre du Temple tirées des archives de S. Gervasio de Cassolas." Revue de l'Orient Latin, no. i I (1 905-1 908): 427-428 (Source edition no. 36, Alexandre IV authorise le grand-maitre et les frères du Temple à percevoir, en Allemagne et partout ailleurs qu’au royaume de Jérusalem [...]).

Delaville Le Roulx, Joseph. "Bulles pour l'ordre du Temple tirées des archives de S. Gervasio de Cassolas." Revue de l'Orient Latin, no. I I (1 905-1 908): 428-429 (Source edition no. 37, Alexandre IV ordonne à l'évéque de Saragosse de protéger les Templiers d'Aragon et de Catalogne et leur biens contre quiconque tenterait de les molester).

Diplomatari d'Alguaire i del seu monestir santjoanista de 1076 a I244. Edited by Jesús Alturo i Perucho. Barcelona: Fundación Noguera, I 999. 
Diplomatari del Masdéu. Vol. III. Edited by Rodrigue,Tretón Barcelona: Fundació Noguera. 2010.

Documentación pontificia de Honorio III (I2I6-I227). Edited by Demetrio Mansilla. Roma: Instituto Español de Historia Eclesiástica I 965.

La documentación pontificia hasta Inocencio III ( $065-1216)$. Edited by Demetrio Mansilla.

Roma: Instituto Español de Estudios Eclesiásticos, I 955.

La documentación pontificia de Inocencio IV (I243-I254). Edited by Augusto Quintana

Prieto. Roma: Instituto Español de Historia Eclesiástica, 1987.

El Gran Priorato de Navarra de la Orden de San Juan de Jerusalén (siglos XII-XIII). Vol. I.

Edited by Santos García Larragueta. Pamplona: Institución Príncipe de Viana, I 957. El Gran Priorato de Navarra de la Orden de San Juan de Jerusalén (siglos XII-XIII). Vol. 2.

Edited by Santos García Larragueta. Pamplona: Institución Príncipe de Viana, I 957.

Goñi Gaztambide, Jose. "Regesta de las bulas de los archivos navarros (II98-I4II)."

Principe de Viana, no. 25 I (2010): 622-623 (Source edition no. 4, Inocencio III perdona la séptima parte de la penitencia a los que socorran a los templarios o se inscriban en su cofradía $[\ldots])$.

Goñi Gaztambide, Jose. "Regesta de las bulas de los archivos navarros (I I 98-I 4 I 7)."

Principe de Viana, no. 25 I (2010): 623 (Source edition no. 7, Inocencio III repite el contenido de la bula del 27 de septiembre de i i 98 en favor de la orden del Hospital).

Papsturkunden für Templer und Johanniter: Archivberichte und Texte. Edited by Rudolf

Hiestand. Göttingen: Vandenhoeck \& Ruprecht, 1972.

Papsturkunden in Spanien: Vorarbeiten zur Hispania Pontificia. II, Navarra und Aragon,

I, Archivberichte. Vol. 2, Part 2. Edited by Paul Kehr. Berlin: Weidmann, I 928.

Regesta de letras pontificias del archivo de la Corona de Aragón. Sección Cancillería Real

(Pergaminos). Edited by Francisco J. Miquel Rosell. Madrid: Cuerpo Facultativo de Archiveros, Bibliotecarios y Arqueólogos, 1948.

\section{SECONDARY SOURCES:}

Ayala Martínez, Carlos de. "De Toledo a las Navas: la reconquista se convierte en cruzada." In Órdenes Militares, monarquía y espiritualidad militar en los reinos de Castilla y León (siglos XII-XIII), edited by Carlos de Ayala Martínez, I 3-44. Granada: Universidad de Granada, 20 i 5 .

Barber, Malcolm. "Supplying the Crusader States: The Role of the Templars." In Crusaders and Heretics, I2th-I4th Centuries, edited by Malcolm Barber, 31 4-326. Aldershot: Ashgate, I 995.

Bonet Donato, María. La Orden del Hospital en la Corona de Aragón: Poder y gobierno en la Castellania de Amposta. Madrid: CSIC, I 994.

Bonet Donato, María and Julia Pavón Benito. "El paisaje de la memoria de la orden del Hospital en la corona de Aragón y Navarra en la edad media." In Historia de la Orden de Malta. Nuevos Estudios, edited by Javier Alvarado and Jaime de Salazar, 85- I 0. Madrid: Dykinson, 2017. 
Borchardt, Karl. “The Military-religious orders: a medieval 'school for administrators'?” In The Military Orders. Vol. V, Politics and Power, edited by Peter W. Edbury, 3-22. Aldershot, Hampshire: Ashgate, 20 I 2.

Bretthauer, Isabelle. "La notion d'écriture pragmatique dans la recherche française du début du XXIe siècle." Cahiers Electroniques d'Histoire Textuelle du LaMOP, 5 (20 I 2): I - I 7. http://lamop-archive.univ-paris I.fr/IMG/pdf/article_Isabelle_Bretthauer-2.pdf

Burgui Fernández, Patricia. "El priorato navarro de la orden de San Juan de Jerusalén a finales de la Edad Media. Berenguer Sanz de Berrozpe ( 1478 - I 5 I 4).” PhD dissertation, Universidad de Navarra, 20 I 4.

Carraz, Damien. "Le cartulaire du Temple de Saint-Gilles, outil de gestión et instrument de pouvoir." In Les cartulaires méridionaux (actes du colloque de Béziers les 20 et $2 I$ septembre 2002 par le Centre historique de recherches et d'études médiévales sur la Méditerranée occidentale, edited by Daniel Le Blévec, I45-162. París: Bibliothèque de l'École des Chartes, 20 i 6.

Delaville Le Roulx, Joseph. "Bulles pour l'ordre du Temple tirées des archives de S. Gervasio de Cassolas." Revue de l'Orient Latin, no. I I (1 905-1 908): 405-439.

Forey, Alan John. The Templars in the "Corona de Aragón." London: Oxford University Press, 1973.

García Fitz, Francisco and Feliciano Novoa Portela. Cruzados en la Reconquista. Madrid: Marcial Pons Historia, 20 I 4.

García-Guijarro Ramos, Luis. Papado, Cruzadas y Órdenes Militares. Madrid: Cátedra, 1995 .

García-Guijarro Ramos, Luis. "San Juan del Hospital: bulas fundacionales y conformación de los rasgos básicos de la orden en la primera mitad del siglo XII." in La Orden de Malta en España. Vol. I, edited by Javier Alvarado y Jaime de Salazar Acha, 95-136. Madrid: Uned-Sanz y Torres, 20 i 5.

Goñi Gaztambide, José. Historia de la bula de la Cruzada en España. Vitoria: Editorial del Seminario, 1958.

Kehr, Paul. Elpapado y los reinos de Navarra y Aragón hasta mediados del siglo XII. Zaragoza: Artes Gráficas E. Berdejo Casañal, 1946.

Le Blévec, Daniel and Alain Venturini. "Cartulaires des Ordres Militaires. XII ${ }^{\mathrm{e}}-\mathrm{XIII}{ }^{\mathrm{e}}$ siècles (Provence occidentale- Basse vallée du Rhône).” In Les Cartulaires, actes de la table ronde organisée par l'École nationale des chartes et le GDR I2I du CNRS (Paris, s-7 décembre I9gI), edited by Olivier Guyotjeannin, Michel Parisse, and Laurent Morelle 45 I-465. Paris: École des Chartes, I 993.

Magnin, Étienne. "Indulgences." In Dictionnaire de théologie catholique contenant l'exposé des doctrines de la théologie catholique, leurs preuves et leur histoire. Vol. 7, Part 2, edited by Alfred Vacant, with Euge' ne Mangenot, I 607-I 6 I o. Paris: Letouzey et Ané, I 923.

Mansilla, Demetrio. "Inocencio III y los reinos hispanos." Anthologica Annua, no. 2 (1 954$)$ : 9-49.

Miret i Sans, Joaquim. Les cases de Templers y Hospitalers en Catalunya. Barcelona: Casa de la Caritat, Barcelona, i 9 iо. 
Pagarolas, Laureà. La comanda del Temple de Tortosa: primer periode (II48-I2I3). Tortosa: Dertosa, I 984.

Peixoto, Michael J. "Copies and cartularies: modernizing Templar documents in mid-thirteenth-century Champagne." In The Templars and their sources, edited by Karl Borchardt, Karoline Döring, Philippe Josserand and Helen Nicholson, 64-77. Abingdon, Oxon: Routledge, 2016.

Smith, Thomas W. Curia and Crusade. Pope Honorius III and the recovery of the Holy Land (I2I6-I227). Turhout: Brepols, 2017.

Ubieto Arteta, Antonio. "Cofrades aragoneses y navarros de la milicia del Temple (siglo XII). Aspectos socio-económicos”, Aragón en la Edad Media, no. 3 ( I 980): 29-93.

Upton-Ward, Judith Mary. The Catalan Rule of the Templars: Edition and Translation: Barcelona, Archivo de la Corona de Aragón. Cartas Reales, MS 3344. Woodbridge: The Boydell Press, 2003.

Zabalo Zabalegui, Javier. La administración del reino de Navarra en el siglo XIV. Pamplona: Institución Príncipe de Viana, I 973. 